Литература двух Америк. 2021. № 10.

Научная стать

https://doi.org/10.22455/2541-7894-2021-10-163-206

УДК 821.111
Literature of the Americas, no. 10 (2021)

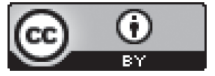

This is an open access article distributed under the Creative

Commons Attribution 4.0

International (CC BY 4.0)

К 110-ЛЕТИЮ ТЕННЕССИ УИЛЬЯМСА

\title{
Максим ГУДКОВ
}

\section{ТЕННЕССИ УИЛЬЯМС В СОВЕТСКОЙ КРИТИКЕ 1940-1960-х ГОДОВ}

Аннотация: В статье предпринимается попытка представить рецепцию драматургии крупнейшего американского писателя Т. Уильямса в советской критике 1940-1960-х гг., показать динамику изменения мнений и оценок ее отечественными литературоведами и театроведами. В позднесталинские годы советские исследователи (М.М. Морозов, В.Я. Голант, А.А. Елистратова, В.М. Гаевский) менее всего занимались литературоведческим анализом его пьес, рассматривая их исключительно сквозь призму идеологии и политической конъюнктуры. Критические суждения сводились к череде оскорбительных комментариев и доказательству заведомой ущербности идеологически чуждого драматурга. В период «оттепели» идеологизированная, клишированная критика, определяющая талант писателя только по принципу его принадлежности к «своим» и «чужим», если и не потеряла своей актуальности, то смягчилась. Появились статьи, авторы которых ставили целью разобраться в своеобразии творческого метода драматурга (Г.П. Злобин, М.О. Мендельсон, Р.Д. Орлова, В.А. Неделин). Анализ рецепции творчества Уильямса советской критикой в 1940-1960-х гг. позволяет утверждать, что признание таланта заокеанского драматурга или, наоборот, инвективы в его адрес были напрямую связаны с общественно-политической ситуацией в СССР и США. Стоило хотя бы немного ослабеть жесткому идеологическому давлению государственной машины, как советские критики начинали руководствоваться критериями объективности и литературного вкуса. В конце исследования дается приложение - библиографический указатель советских критических статей о Т. Уильямсе (1947-1969 гг.), представляющий собой попытку создания полного библиографического указателя советских критических статей о творчестве Т. Уильямса в 1940-60-е гг.

Ключевые слова: Т. Уильямс, американская драматургия, советская критика, холодная война, советско-американские культурные связи.

Информация об авторе: Максим Михайлович Гудков, старший преподаватель, Санкт-Петербургский государственный университет, Университетская наб., д. 7-9, 199034 г. Санкт-Петербург, Россия. ORCID ID: https://orcid.org/0000-0003-3956-4981. E-mail: m.gudkov@spbu.ru.

Для цитирования: Гудков М.М. Теннесси Уильямс в советской критике 1940-1960-х годов // Литература двух Америк. 2021. № 10. C. 163-206. https://doi.org/10.22455/2541-7894-2021-10-163-206.

Автор статьи считает своим приятным и почетным долгом выразить глубокую признательность руководству Исторической коллекции Нового Орлеана - Исследовательскому центру Уильямса (The Historic New Orleans Collection - Williams Research Center) - а именно Ричарду Бартону Палмеру, Марку Кейву и Ребекке Смит - за щедро подаренную фотографию Т. Уильямса и согласие на безвозмездную публикацию ее в настоящем издании. 
Research Article

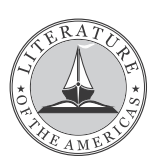

Literature of the Americas, no. 10 (2021)

https://doi.org/10.22455/2541-7894-2021-10-163-206

UDC 821.111

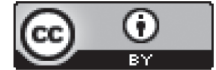

This is an open access article distributed under the Creative Commons Attribution 4.0 International (CC BY 4.0)

\section{TENNESSEE WILLIAMS 110 BIRTH ANNIVERSARY}

\section{Maxim GUDKOV}

\section{TENNESSEE WILLIAMS IN SOVIET CRITICISM OF THE 1940-1960s}

Abstract: The article attempts to present the reception of the plays by Tennessee Williams in Soviet criticism of the 1940s and 1960s to show the dynamics of changing opinions and assessments by Soviet literary and theater critics. In the late Stalinist years Soviet researchers (Michael Morozov, Veniamin Golant, Anna Elistratova, Vadim Gaevsky) were least engaged in the literary analysis of his plays, which they considered exclusively through the lens of ideology and politics. Critical judgments were reduced to a series of offensive comments on the "inferiority" of the "ideologically alien" playwright. During the Khrushchev Thaw the ideologically bound criticism were being gradually softened, its clichees being no longer relevant. There appeared articles by Georgy Zlobin, Moris Mendelson, Raisa Orlova, Vladich Nedelin, etc., that aimed to understand Williams' peculiar and unique creative method. The analysis of the reception of Williams' work by Soviet critics in 1940-1960s demonstrates that the recognition of the American playwright's talent or, conversely, harsh language used against him was directly related to the political situation in the USSR and the United States, as well as to the Soviet-American relations in the realm of politics and cultural ties. As soon as the rigid ideological pressure of the state machine was relieved to some extent, Soviet critics followed the criteria of objectivity and literary taste. The study is supplemented by the bibliographic index of Soviet criticism of Tennessee Williams works, 1947-1969. The addendum is an attempt to create a complete bibliography of Soviet critical articles about Tennessee Williams's work published in the 1940-60s.

Keywords: Tennessee Williams, American drama, Soviet criticism, Cold War, Soviet-American cultural links.

Information about the author: Maksim M. Gudkov, Senior Lecturer, St. Petersburg University, Universitetskaya nab. 7-9, 199034 St. Petersburg, Russia. ORCID ID: https://orcid.org/0000-0003-3956-4981. E-mail: m.gudkov@ spbu.ru.

For citation: Gudkov, Maksim. "Tennessee Williams in Soviet Criticism of the 1940-1960s." Literature of the Americas, no. 10 (2021): 163-206. https://doi.org/10.22455/2541-7894-2021-10-163-206.

The author of the article considers it a pleasant and honorable duty to express his deep gratitude to the management of The Historic New Orleans Collection - Williams Research Center, - namely, Richard Barton Palmer, Mark Cave and Rebecca Smith — for the generously donated photo of T. Williams and for agreeing to publish it free of charge in this publication. 
Начало творческого пути крупнейшего американского драматурга Теннесси Уильямса (Tennessee Williams, 1911-1983), так же, как и ранние попытки критического осмысления его пьес в нашей стране, пришлись на позднесталинские годы основательного официального антизападничества - период ждановщины и кампанию по борьбе с космополитизмом. Несмотря на то, что мировую известность драматург приобрел вместе с пьесой-воспоминанием «Стеклянный зверинец» (The Glass Menagerie, 1944) еще в годы Второй мировой войны, в Советском Союзе его произведения получили заслуженное признание только на рубеже 1960-1970-х гг. ${ }^{1}$

Степень известности американского драматурга в СССР до того, как в 1970 г. в Московском академическом театре имени В.В. Маяковского режиссер А.А. Гончаров поставил легендарный «Трамвай “Желание”» (A Streetcar Named Desire, 1947)2, справедливо определил завлит этого театра В.Я. Дубровский:

О Теннесси Уильямсе до определенного времени знали больше понаслышке - пьесы не переводились, спектакли мало кто видел; была немногословная информация о зарубежных постановках, да еще слух о фильме «Трамвай “Желание”» с Вивьен Ли и молодым Марлоном Брандо [Джигарханян, Дубровский 2002: 74].

Действительно, редкие в 1940-1960-е гг. советские критические статьи о драматургии Уильямса писались в обстоятельствах «железного занавеса», когда сами граждане СССР не могли прочитать или посмотреть его пьесы, — т. е. по сути им предлагалось на слово поверить критику. Впервые в СССР уильямсовскую драматургию напечатали лишь в 1960 г.: в журнале «Иностранная литература» была опубликована пьеса «Орфей спускается в ад» (Orpheus Descending, 1955) [Уильямс 1960], а следом она вышла малотиражным стеклографическим изданием отдела распространения драматических произведений Всесоюзного управления по охране авторских прав (ВУОАП)

1 Этим и определяются временны́е рамки нашего исследования. Они позволяют проследить рецепцию советской критикой всех лучших пьес Т. Уильямса, что называется, «золотого фонда» его драматургии, написанного им до глубокого и затяжного кризиса 1960-х, - «самого страшного периода в <его> жизни» [Уильямс 2001: 262].

2 См. об этом спектакле: [Гудков 2021; Gudkov, Freese 2022]. 


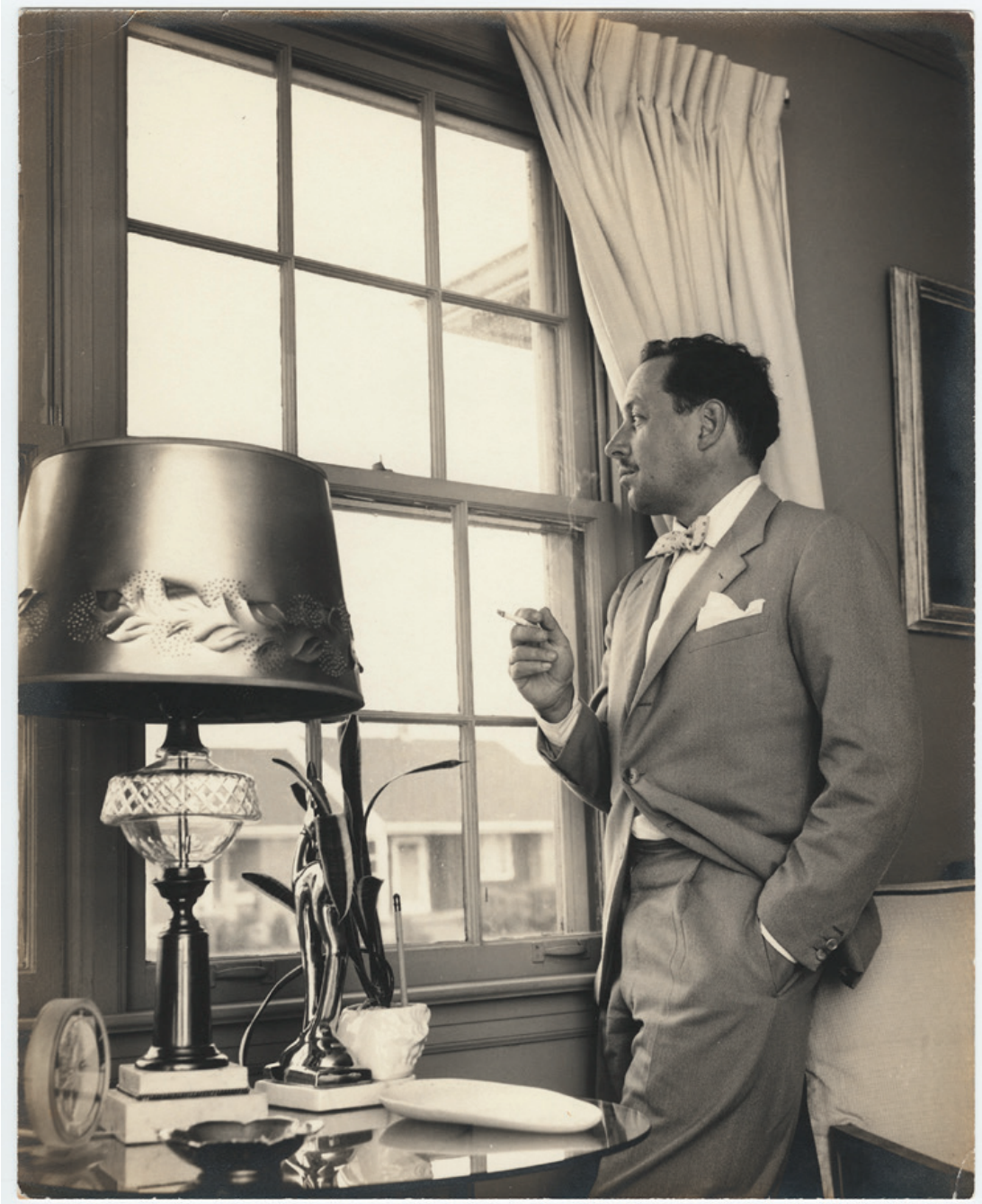

Теннесси Уильямс, стоящий у окна. 1947 (?).

Источник: Историческая коллекция Нового Орлеана - Исследовательский центр Уильямса (The Historic New Orleans Collection - Williams Research Center).

[Уильямс 1961]. Первый сборник пьес Уильямса на русском языке [Уильямс 1967] ${ }^{3}$ увидел свет в 1967 г.

3 В него вошли следующие пьесы: «Несъедобный ужин» (Unsatisfactory Supper, 1938), «Растоптанные петунии» (The Case of the Crushed Petunias, 1942), «Предназначено на слом» (This Property is Condemned, 1941), «Любовное письмо 


\section{МОСНОВСНИЙ AНАДЕМИЧЕСНИЙ TEATP

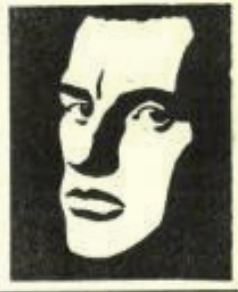

28, 29 января $1971 \mathrm{r}$.

\section{ПPEMBEPA}

3, 10, 17 и 24 февраля 1971 r.

Теннесси уильямс
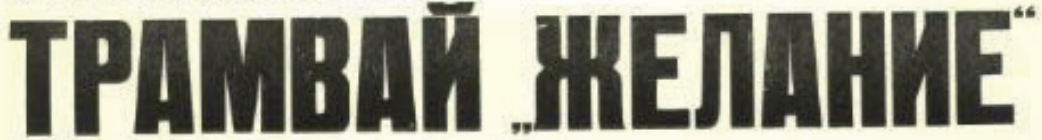

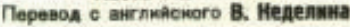

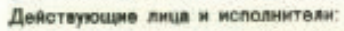

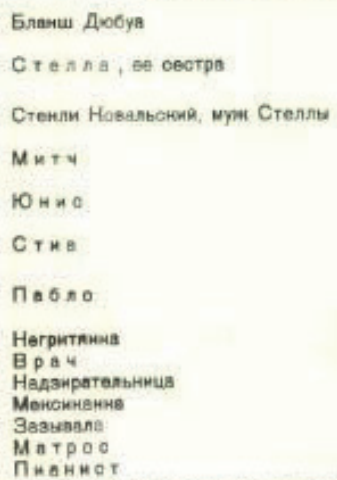

- E. Н. Козырева

C. B. Hemongesa

- C. Н. Мизери

г. и. Яцкина

- A. 5. Амигарханян

E. H. Nasapes

- и. л. охлупин

и. M. Соренко

- r. А. Анисимова

C. A. Зайова

- В. Ф. Козиов

Б. I. Xимичеs

- П. М. Арманов

K. A. Мукасян

- T. Н. Buнorpanosa

- C. H. Прусаков

- T. К. Бабамина

- C. K. Makaposa

- A. П. Назаров

- ю. Н. Перов

- B. A. Haymeu

В эпиэсдах О. В. Бламиевич, Н. Л. Верова, В. В. Вишияк, М. И. Езепов, Г. И. Жилко, г. Г. Федотова, г. К. 10рнова

Поствновна азслунвеного деятела иснуботв РСФСР А. А. ГОНЧАРОВА Рентосор - 5. C. Комдратье:

ХУАСННИНИ - 10. В. БОГОЯВЛЕНСКИИ, В. А. КОНОВАЛОВ

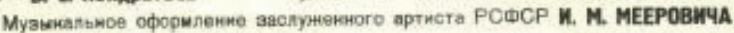

Худонния по коспомам - Л. М. Кусаноеа

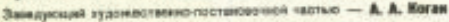

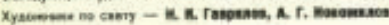

rewi - A. B. Pabscest

Hlo. pemscenpa - T. E. CASAREEBA

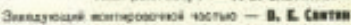

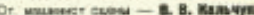

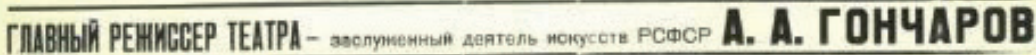

$$
\text { - }
$$

Афиша спектакля «Трамвай “Желание”» Московского академического театра имени В.В. Маяковского (1970).

Источник: Музей Московского академического театра имени В.В. Маяковского. 
Хотя о Т. Уильямсе в СССР долгое время почти ничего не знали, (как справедливо отмечает современный исследователь Д.С. Лапенков) «отечественное уильямсоведение, как и американское, начало развиваться в конце 1940-х годов. Первые статьи о пьесах драматурга носили, однако, явно выраженный негативный характер» [Лапенков 2018: 4].

С началом холодной войны репертуар советского театра стал жестко регламентироваться, - в нем обязательно должны были преобладать современные отечественные пьесы, осуждающие «низкопоклонство перед Западом» и обличающие американский империализм. Основные требования госзаказа были оформлены в постановлении руководства ЦК ВКП(б) от 26 августа 1946 г. под названием «О репертуаре драматических театров и мерах по его улучшению».

После обвинений в том, что «увлечение иностранщиной засоряет репертуар советского театра» (цит. по: [Гудкова 2009: 194]), от былого в 1920-1930-е гг. разнообразия присутствия на отечественной сцене спектаклей по заокеанским авторам не осталось и следа. Прекратили у нас и печатать драматургию США. Показательно расправилось советское руководство с каким-то чудом изданным в 1946 г. сборником «Английские и американские пьесы в одном действии» [Английские и американские пьесы 1946] $]^{4}$. В постановлении «О репертуаре...» утверждалось:

[...] Комитет по делам искусств ведет неправильную линию, внедряя в репертуар театров пьесы буржуазных зарубежных драматургов. Издательство «Искусство» по заданию Комитета по делам искусств выпустило сборник одноактных пьес современных английских и американских драматургов. Эти пьесы являются образцом низкопробной и пошлой зарубежной драматургии, открыто проповедующей буржуазные взгляды и мораль. [...] Постановка театрами пьес буржуазных зарубежных авторов явилась, по существу, предоставлением

лорда Байрона» (Lord Byron's Love Letter, 1943), «Стеклянный зверинец», «Трамвай “Желание”», «Лето и дым» (Summer and Smoke, 1948), «Орфей спускается в ад», «Ночь игуаны» (The Night of the Iguana, 1959) и «Гнэдигес Фройлайн» (The Gnadiges Fraulein, 1966).

4 Из семи одноактовок этого сборника лишь три принадлежат американским драматургам: «Таков Голливуд» (Glamour Preferred, 1940) Ф. Райерсон и К. Клементса, «Жена за полкроны» (The Wife of a Half-Crown, 1938) Р.Э. Митчелла и «Быка отравили» (This is Villa!, 1938) Д. Ниггли. 
советской сцены для пропаганды реакционной буржуазной идеологии и морали, попыткой отравить сознание советских людей мировоззрением, враждебным советскому обществу, оживить пережитки капитализма в сознании и быту (цит. по: [Власть и художественная интеллигенция 1999: 592]).

Лишь крайне редкие пьесы американских драматургов, настроенных просоветски, достигали в эти годы советских подмостков: 1947 г. — «Глубокие корни» (Deep Are the Roots, 1945) Дж. Гоу и А. Д'Юссо в Ленинградском театре драмы имени А.С. Пушкина и Московском театре имени Е.Б. Вахтангова; 1948 г. — «Все мои сыновья» (All My Sons, 1947) А. Миллера в Московском театре имени Е.Б. Вахтангова и Ленинградском БДТ имени А.М. Горького; 1949 г. «За лесами» (Another Part of the Forest, 1946) Л. Хеллман в Московском театре драмы (под названием «Леди и джентльмены»).

Столь разительно отличающаяся от канонов соцреализма драматургия Т. Уильямса, в которой «так сильно звучат мотивы фрейдизма, неосознанных и стихийных, неподвластных человеку и его разуму страстей и желаний» ${ }^{5}$, не оказалась в списке иностранных пьес, допущенных к постановке на советской сцене. Советский критик возмущенно вопрошал:

Что дает театрам обращение к этой пьесе («Трамвай “Желание"». - М. Г.) в смысле - не будем стесняться этих слов, ибо в них - главное назначение театра, суть всей его деятельности коммунистического воспитания зрителя?.. ${ }^{6}$.

Таким образом, драматургия Уильямса воспринималась и оценивалась в СССР, с одной стороны, через призму идеологии, а с другой - в русле соответствия эстетике и этическим нормам, принятым в Советском Союзе.

Три самых ранних в СССР критических высказывания об Уильямсе принадлежали авторитетному отечественному литературоведу, театроведу и переводчику Михаилу Михайловичу Морозову (1897-1952), посвятившему всю жизнь изучению творчества Шекспира, одному из основателей советского научного шекспироведения.

\footnotetext{
5 Зубков Ю.А. Первый сезон // Театральная жизнь. 1971. № 19 (октябрь). С. 23.

6 Там же.
} 
Поскольку с 1937 г. он возглавлял Кабинет Шекспира и западноевропейского театра, созданный при Всероссийском театральном обществе (BTO), то он был хорошо знаком с новыми пьесами США, в том числе произведениями Т. Уильямса.

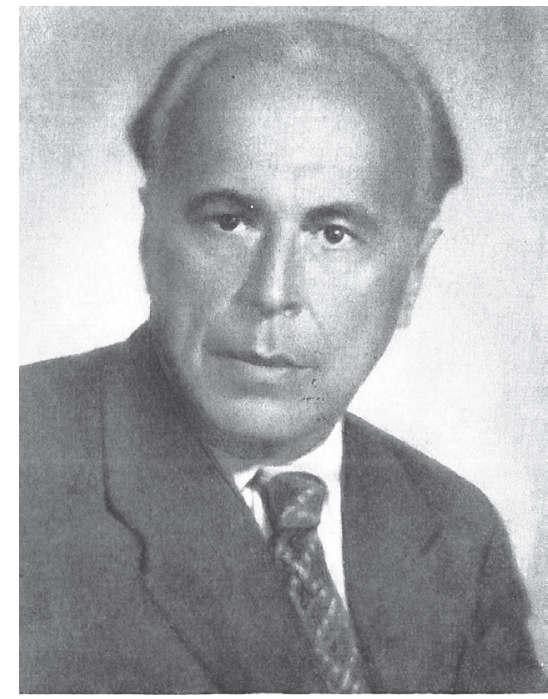

М.М. Морозов. Конец 1940-х.

В 1947 г. в газете «Советское искусство» М.М. Морозов опубликовал объемную статью о современной американской драматургии - под типичным для той эпохи названием «Во власти доллара», в которой «прошелся» и по уильямсовскому «Стеклянному зверинцу»:

Разновидность театрального бизнеса - пустые, бессмысленные «шоу» - представления с пением и танцами. Их постановщики стараются завлечь публику внешним блеском спектакля. [...] Намек на подлинный характер этих представлений, ошеломляющих зрителя своим внешним блеском и всячески притупляющих его сознание, дан в пьесе Теннеси Вильямса «Стеклянный зверинец». Правда, в ней речь идет о фильмах, а не о театре, но по существу это не меняет дела. Невыносимые условия труда превратили героя этой пьесы - мелкого американского служащего - в некое подобие автомата, робота. По вечерам он неизменно отправляется в кино, упиваясь приключенческими фильмами, как наркозом. [...] Автор ни словом не обмолвился о причинах страданий «маленького человека» в США, не указал выхода из них, зато он щедро разукрасил свою пьесу всевозможными формальными трюками (например, введя киноэкран в драматический спектакль). В результате даже страдания «маленького человека» служат своего рода аттракционом... «Я подаю вам правду в приятном одеянии иллюзий», - говорит Вильямс. От этого «приятного одеяния» веет отвратительным запахом тления ${ }^{7}$.

7 Морозов М.М. Во власти доллара // Советское искусство. 1947. 11 октября. № 41 (1077). C. 4. 
Как видно, это самое первое в СССР упоминание Уильямса уже изобилует обязательными для отечественного антиамериканизма тех лет «разоблачительными» клише - уподобление «маленького человека» в капиталистическом мире «автомату, роботу», непростительное увлечение формализмом («формальные трюки»), деградация западной культуры («отвратительный запах гниения»), а также равнодушие к остросоциальным проблемам («ни словом не обмолвился о причинах... не указал выхода»).

Название этой статьи и ее обличительный пафос полностью соответствовал риторике программной антиамериканской публикации К.М. Симонова 1946 г., озаглавленной схожим образом — «Власть денег» ${ }^{8}$. Крупный советский писатель сразу же после своей поездки за океан (апрель — июнь 1946 г.) категорично заявлял в духе сталинского послевоенного антизападничества:

Я видел в Нью-Йорке больше десятка спектаклей. Содержание и общее направление этих пьес - тема для отдельного разговора. В качестве общей характеристики можно сказать, что трудно представить себе что-нибудь более нарочито уводящее от всех сколько-нибудь серьезных общественных проблем, мучающих лучшую, прогрессивную часть американского общества, чем содержание большинства этих пьес. [...] Нелепая власть денег уничтожала жизнь и душу в искусстве, превращая его в производство, где предмет эксплоатации - актеры, а цель - нажива. [...] Система жизни американского театра - система, в высшей мере чуждая искусству и отдающая человека искусства в рабство доллару 9 .

Через пару месяцев - 21 ноября 1946-го - прозвучал доклад Симонова «Драматургия, театр и жизнь», текст которого тут же был опубликован в «Правде» и «Советском искусстве», а на следующий день - и «Литературной газете» ${ }^{10}$. В этом докладе в соответствии

8 Симонов К.М. Власть денег (Заметки об американском театре) // Культура и жизнь. 1946. 30 августа. № 7. С. 3-4.

9 Там же. С. 4.

10 Симонов К.М. Драматургия, театр и жизнь // Правда. 1946. 22 ноября. № 277 (10359). С. 3; Симонов К.М. Драматургия, театр и жизнь (Из доклада) // Советское искусство. 1946. 22 ноября. № 48 (1032). С. 2; Симонов К.М. Драматургия, театр и жизнь (Из доклада) // Литературная газета. 1946. 23 ноября. № 47 (2310). С. 2. 
с риторикой начавшейся холодной войны писатель настойчиво взывал ко всем отечественным деятелям литературы и сцены:

На идеологическом фронте во всемирном масштабе с небывалым ожесточением идет один огромный бой. [...] Во всеуслышание, на весь мир с трибуны нашего искусства мы говорим и будем говорить о том, что мы боремся и будем бороться за коммунизм, о том, что мы считаем, что коммунизм - это единственно правильный путь в будущее для человечества [Симонов 1953: 32-33].

Еще раз об уильямсовском «Стеклянном зверинце» М.M. Морозов написал в своей статье для журнала «Театр» в том же 1947 г. Здесь советский ученый уже в более развернутом виде, по сути, повторил прежнюю оценку пьесы. Из новых его тезисов наиболее спорным является следующий:

Пьеса Вильямса напоминает тяжелый кошмар. Чтобы усугубить это впечатление, автор всячески настаивает в ремарках на «ирреальности» своей пьесы. «Это - пьеса, основанная на памяти, — пишет Вильямс, - она освещена тусклым светом, она сентиментальна, ирреалистична» ${ }^{11}$ (курсив наш. — М. Г.).

Поразительно, что подобные слова Морозов пишет о самой «прозрачной», легкой, воздушной и светлой драме Уильямса, — такой же «хрустальной» и хрупкой, как игрушечный единорог главной героини Лауры Уингфилд. Свой тезис ученый подтверждает не вполне корректным переводом ремарки, которая в оригинале выглядит так:

The scene is memory and is therefore nonrealistic (курсив наш. М. Г.). Memory takes a lot of poetic license. It omits some details; others are exaggerated, according to the emotional value of the articles it touches, for memory is seated predominantly in the heart. The interior is therefore dim and poetic [Williams 1967: 276].

В замечательном переводе советского литературоведа и исследователя американской литературы Георгия Павловича Злобина

11 Морозов М.М. Две культуры // Театр. 1947. № 11. С. 62. 
(1927-2014), многократно писавшего об Уильямсе в конце 1950-х 1960-е гг., эта ремарка дается следующим образом:

Действие пьесы - воспоминания человека, и потому обстановка нереалистична (курсив наш. - М. Г.). Память своевольна, как поэзия. Ей нет дела до одних подробностей, зато другие проступают особенно выпукло. Все зависит от того, какой эмоциональный отзвук вызывает событие или предмет, которого коснется память; прошлое хранится в сердце. Оттого и интерьер видится в туманной поэтической дымке [Уильямс 1967: 73].

Основное качество пьесы Уильямса - «нереалистичность» ("nonrealistic") заменяется Морозовым более агрессивным понятием «ирреальность», которое соответствует синонимическому ряду с негативной коннотацией: химеричность, иллюзорность, призрачность, фиктивность, обманчивость. В позднесталинской России признавалась исключительно реалистическая драматургия, а точнее - та, что была написана по канонам социалистического реализма. На сценических подмостках господствовал помпезный, выхолощенный монументализм и натуралистическое «настырное жизнеподобие» [Соловьева 1998: 175]:

Сценическое многообразие поисков 1920-х как советского театра в целом, так и самого МХАТа к концу 1930-х годов усилиями сталинской культурной политики оказалось сведено к единому и обязательному для всех театров страны искусству жизнеподобия. Все другие подходы вне зависимости от авторской поэтики были объявлены формализмом [Черкасский 2016: 194].

С усилением идеологического диктата в СССР было покончено с режиссерским «многоголосием» на сцене, и начался насильственный процесс так называемого «омхачивания» всех театров. Советские руководители от культуры идеологизировали систему К.С. Станиславского, увязав ее исключительно с соцреализмом:

После смерти Станиславского и канонизации его учения система не раз была призвана освящать и оправдывать сценическую ложь, против которой основатель МХТ боролся всю жизнь. Именно тогда система стала отождествляться с определенной эстетикой, прежде 
всего с эстетикой бытового, натуралистического театра [Смелянский 1989: 14].

Далекий от натурализма «Стеклянный зверинец» (что декларировалось Уильямсом в самом начале пьесы ${ }^{12}$ ) вызывал у М.M. Морозова негодование:

Подобно причудливым растениям, беспрерывно появляются на экране образы и надписи (смесь театра и кино, как известно, - форма, излюбленная в США), столь же бьющие по нервам, пряные, как и сопровождающая спектакль «надрывная» музыка фокстротов и танго. Бледная, больная девушка лежит на диване. И вот на экране появляются голубые розы. Есть в этом дешевом эстетизме, проникнутом сексуальностью, что-то глубоко противное... Нет, эта пьеса не рассеет мрака в «темной комнате»! Наоборот, у многих сидящих в зрительном зале «Томов» (Том - главный герой этой пьесы. - M. Г.) бессильно опустятся руки: «все равно, подумают они, томление наше бесцельно и бессмысленно» ${ }^{13}$.

Третий раз М.М. Морозов обратился к драматургии Уильямса в 1948 г, опубликовав в газете «Советское искусство» статью о «Трамвае “Желание”». Идею нового уильямсовского произведения он интерпретировал своеобразно:

Старая Америка умирает, к хозяйскому месту пробирается «новый человек» - такова основная тема пьесы. Этот «новый человек» показан в образе грубого, жестокого, не брезгующего самыми грязными средствами молодца, по имени Стэн. Согласно концепции драматурга, его герой обладает «первобытной силой». Перед этой силой не может устоять героиня пьесы Стелла. Вот типичная для спектакля мизансцена. На вершине металлической винтовой лестницы стоит Стелла в белом платье, ярко освещенная лучами прожекторов. У подножия лестницы ожидает ее Стэн. И Стелла, понурив голову, медленно сходит вниз. Ее белый длинный шлейф беспомощно сколь-

12 См.: «Традиционная реалистическая пьеса с настоящим холодильником и кусочками льда, с персонажами, которые изъясняются так же, как изъясняется зритель, - это то же самое, что и пейзаж в академической живописи, и обладает тем же сомнительным достоинством - фотографическим сходством» [Уильямс 1967: 70].

13 Морозов М.М. Две культуры. С. 62-63. 
зит по ступеням. Она лишена воли: ее влечет, по словам рецензента, «первобытная сила» ${ }^{14}$.

Знаковую, крайне эмоциональную и чувственную сцену отклик героини в исполнении Ким Хантер на раздирающий душу крик-вопль Марлона Брандо «Стелла-а-а!», ставшую одним из «вершинных достижений» [Черкасский 2016: 655-656] актерского искусства США - стерильная эстетика соцреализма не могла принять. Парадоксально, что исполнитель роли Стэнли - молодой М. Брандо - являлся воспитанником знаменитого «Метода» Л. Страсберга, сформированного под существенным влиянием именно российской театральной школы (прежде всего идей К.С. Станиславского, Е.Б. Вахтангова и В.Э. Мейерхольда).

И далее М. Морозов излагал собственное понимание пьесы Уильямса:

Сестра Стеллы, Бланш, тщетно ищет спасения от невыносимой действительности в «моральных устоях прошлого». Эти устои оказываются призрачными. Бланш, охваченная отчаянием, предается разврату и пьянству и, в конце концов, сходит с ума. Итак, согласно Вильямсу, выхода нет, надо либо покориться «первобытной силе», как Стелла, либо сойти с ума, как Бланш ${ }^{15}$.

Как проводник официальной антизападнической линии в театральной критике, М. Морозов декларировал:

Огромная часть современной американской драматургии охвачена гангреной отвратительного разложения. Гангстеры, тянущиеся трясущимися руками к грудам золота; бредовые кошмары в духе «черных» пьес Сартра; садистическое смакование чудовищных жестокостей, являющееся по существу откровенной проповедью преступления; пошлое зубоскальство крикливых, шумных и бессмысленных «шоу» и «ревю», - от всего этого подымаются невыносимо душные испарения, отравляющие сознание массового зрителя [Морозов 1947: 339].

14 Морозов М.M. Культ грубой силы // Советское искусство. 1948. 25 сентября. № 39 (1127). C. 4.

15 Там же. 
Один к одному морозовские слова о «Трамвае “Желание”» повторил в статье 1949 г. ленинградский публицист и историк Вениамин Яковлевич Голант (1912-1974):

Мастером [...] демагогии является Теннесси Вилльямс — автор пьес «Стеклянный зверинец» и «Трамвай, называемый желанием». На первый взгляд может показаться, что автор сочувственно относится к трагедии маленького человека, задавленного гнетом капитала. Но «сочувствие» Вилльямса лишь наживка, вместе с которой зритель должен проглотить и крючок. Крючок этот - убеждение в бессмысленности борьбы за улучшение своего положения, мораль кролика, покорно дожидающегося, чтобы его проглотил удав. Героиня последней пьесы Вилльямса - Бланш Дюбуа, не приемлющая этой морали, сходит с ума. А сестра ее Стелла находит свое счастье в том, что становится рабою грубого и жестокого хищника, от которого исходит неотразимая «примитивная сила» ${ }^{16}$.

Подчеркнем, что эти строки о драматургии Уильямса были напечатаны в журнале «Звезда», который вместе с другим изданием под названием «Ленинград» только что подвергся идеологической атаке Жданова (постановление от 14 августа 1946 г.) и теперь, находясь под особым пристальным контролем цензоров, «исправлялся».

К 1949 г. кампания по борьбе с космополитизмом и «преклонением перед Западом» достигла пика и нанесла окончательный удар, в том числе, и по американской драматургии. Программная редакционная статья «Литературной газеты» клеймила «антипатриотическую группу театральных критиков»:

Космополитизм - чуждость жизни и историческим интересам своего народа, холуйское преклонение перед буржуазной культурой Запада и столь же холопское непонимание великой ценности могучей русской национальной культуры и культуры других братских народов СССР. Космополит, злорадно хихикая, силится во что бы то ни стало «обнаружить» ту или иную «параллель», ту или другую примету сходства явлений русской культуры с культурой Запада. [...] Космополитизм, презренный уже со времен своего зарождения, в нашу эпоху является прямым орудием черной империалистической реакции. [...]

16 Голант В.Я. Отравители // Звезда. 1949. № 4. С. 140. 
Враждебная советской драматургии «деятельность» [...] антипатриотической группы (театральной критики. советской художественной литературы, пыталась заставить советскую драматургию [...] капитулировать перед космополитической буржуазной драматургией. Эта вредная деятельность сосредоточивалась прежде всего в недрах Всероссийского театрального общества, в газете «Советское искусство», журнале «Театр», в комиссии по драматургии Союза писателей ${ }^{17}$.

Вскоре, 1 марта 1949 г., в Агитпропе ЦК был разработан «План мероприятий по усилению антиамериканской пропаганды на ближайшее время», который предусматривал масштабное и систематическое издание во всех ведущих советских СМИ материалов, «разоблачающих агрессивные планы американского империализма, антинародный характер общественного и государственного строя США, развенчивающих басни американской пропаганды о “процветании” Америки», показывающих «вырождение культуры в США», «упадок современного американского театра» (см.: [Сталин и космополитизм 2005: 321-322, 324-325]).

В соответствии с этим планом в сентябре 1949-го газета «Правда» опубликовала анонимную разгромную статью, где упоминалась пьеса Уильямса «Трамвай “Желание”». Поразительна трактовка образа главной героини:

На Бродвее уже второй год идет пьеса Теннеси Вильямса под заумным названием «Трамвай, называющийся желание». В этой пьесе Вильямс выводит женщину, одержимую своеобразной манией: героиня пьесы убеждена, что перед ней не может устоять ни один мужчина. Все действие происходит в грязной, запущенной квартире ее замужней сестры в Нью-Орлеане. Героиня прибывает сюда в поисках мужчин. Потерпев полную неудачу и оказавшись соблазненной собственным шурином, она окончательно сходит с ума, и пьеса заканчивается тем, что ее отправляют в дом для умалишенных ${ }^{18}$.

17 До конца разоблачить антипатриотическую группу театральных критиков // Литературная газета. 1949. 29 января. № 9 (2496). С. 1.

18 Театр на службе реакции (Письмо из Нью-Йорка) // Правда. 1949. 6 сентября. № 249 (11356). С. 3 . 
Обратим внимание на то, что название пьесы «Трамвай “Желание"» критик определял словом «заумное». Действительно, его образность разительно отличается от заголовков всего массива советской драматургии, разрывающей с классической дореволюционной русской драмой. Метафоричность названия уильямсовской пьесы контрастирует с традицией социалистического драматургического канона, начавшей формироваться еще в 1920-1930-е гг.:

Названия большинства ранних советских пьес, как правило, фиксируют плоскостное видение мира: «Кровавый берег», «Красная купель», «Приговор». [...] Небывалое в XX веке сужение представлений о человеке в складывающейся литературе нового социалистического типа впервые фиксируется именно в заголовках ранних драм [Гудкова 2008: 351].

В отечественной послевоенной драматургии эта тенденция обрела еще более выраженные черты:

Открывая пьесы, озаглавленные как «Шакалы» (автор эстонский драматург Аугуст Якобсон, 1950) или «Заговор обреченных» (Николай Вирта, 1949, Сталинская премия), читатель сразу понимает, как именно будет выстроена система образов. Авторская оценка нескрываема. Столь же однозначны и названия типа: «Люди доброй воли» (Георгий Мдивани, 1950), «Великая сила» (Б. Ромашов) либо «Закон чести» (Александр Штейн, 1950). [...] По своей поэтике антиамериканские пьесы 1940-х — начала 1950-х — частный случай общей кондовости заказных опусов. Е. Добренко еще в 1990 году писал, что в литературе сталинского соцреализма человек сведен либо к должности, либо к профессии [Гудкова 2009: 202].

Досадную «лепту» в дело компрометации в нашей стране драматургии Уильямса внесла и крупный отечественный исследователь, руководитель группы «западников» Института мировой литературы Анна Аркадьевна Елистратова (1910-1974). В год смерти Сталина — в 1953-м - в одной из своих статей на страницах «Правды» она назвала Бланш Дюбуа «спившейся потаскушкой», а пьесу «Лето и дым» - «скучнейшей драмой», увидев в ней лишь «вымученную символику» ${ }^{19}$.

19 Елистратова А.А. Пропаганда безнадежности (Заметки о современных американских буржуазных пьесах) // Правда. 1953. 24 мая. № 144 (12712). С. 3. 
Первая монографическая, «персональная» статья, посвященная исключительно Уильямсу, оказалась возможной лишь после смерти Сталина — в эпоху хрущевской оттепели (1956-1964), когда в Советский Союз «сквозь щели в железном занавесе стали просачиваться зарубежные театральные коллективы. [...] И отечественный театр постепенно стал делаться разным - и с репертуарной точки зрения, и в плане художественно-постановочных решений» [Жидков 1995: 211]. В атмосфере всеобщего обновления на советскую сцену не просто возвращалась, а «хлынула зарубежная драматургия» ${ }^{20}$. В одной только Москве, например, в сезон 1962/63 гг. были поставлены «Сейлемские ведьмы» А. Миллера и «Трехгрошовая опера» Б. Брехта в Театре имени Станиславского, «Суббота, воскресенье, понедельник» Э. Де Филиппо и «Сотворившая чудо» У. Гибсона у «ермоловцев», «Романьола» Л. Скурацина в Театре имени Пушкина, «Физики» Ф. Дюрренматта в ЦАТСА, «Милый лжец» Дж. Килти во МХАТе и «Двое на качелях» У. Гибсона в «Современнике». Естественно, что среди зарубежной драматургии предпочтение отдавалось пьесам из стран социалистического лагеря, а лишь затем - капиталистического, причем в последних необходимо было отразить идеологические недостатки буржуазного мира, продемонстрировав прогрессивность СССР. Однако цензура и пресловутые «худсоветы» продолжали еще жестко контролировать афишу театров, и попасть в нее писателю из США было почти невозможно.

Автором первой полностью «уильямсовской» статьи 1958 г. под названием «Теннесси Вильямс - драматург “без предрассудков”» выступил недавний выпускник театроведческого факультета ГИТИСа, впоследствии ставший видным искусствоведом, Вадим Моисеевич Гаевский ${ }^{21}$ (р. 1928). Именно он предпринял первую в СССР попытку определить особенности художественного стиля Т. Уильямса. Продолжая по традиции крайне негативно оценивать творчество драматурга, он характеризует его как «моралиста-порнографа», а его стиль определяет как «цинический реализм» ${ }^{22}$. С позиций диамата

20 Любимов Б.Н. <Интервью с В.Я. Вульфом>. Театральный мост: Об американской драме на московской сцене // Литературное обозрение. 1988. № 10. C. 79 .

21 Гаевский В.М. Теннесси Вильямс - драматург «без предрассудков» // Театр. 1958. № 4. С. 181-183.

22 Там же. С. 183. 
не приемля психоанализ, советский критик расправлялся с мировоззрением «драматурга “без предрассудков”»:

Тема, которую преимущественно разрабатывает Вильямс, тема смятения чувств, тема сексуальных тревог и вожделений, доведенных до такой степени, при которой они перестают быть явлением психологического порядка и становятся явлением клиническим. Бунт плоти, буйство плоти, опустошительные набеги инстинкта, циническое попрание разума, воли, воспитания, социальных

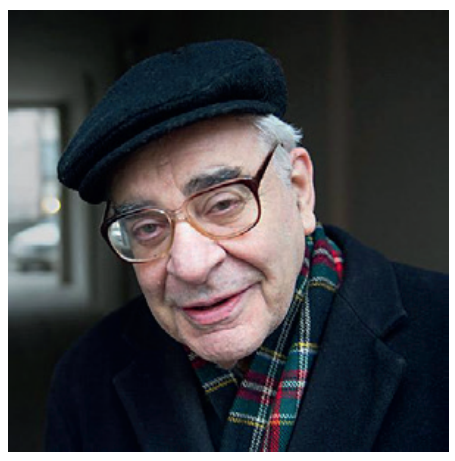

В.М. Гаевский. 2012. запретов и социальных условностей, а в довершение всего - маразм личности - вот, собственно говоря, содержание пьес Вильямса, в основу которых положены широко распространенные сейчас на Западе фрейдистские представления о существе и механизме психической деятельности личности ${ }^{23}$.

Анализируя ряд уильямсовских пьес — «Трамвай “Желание”», «Татуированную розу» (The Rose Tattoo, 1950) и «Кошку на раскаленной крыше» (Cat on a Hot Tin Roof, 1955), — В.М. Гаевский приходил к следующему выводу:

Особенность Вильямса как реакционера современного и реакционера американского заключается в том, что грубо оклеветанной мысли победоносно противопоставляются у него разнузданные инстинкты и циничное стяжательство ${ }^{24}$.

Обобщая главную специфику позднесталинской советской критики драматургии Т. Уильямса, можно заключить, что литературоведческий анализ его пьес и исследование своеобразия творческого метода в этот период менее всего интересовали отечественных авторов (М.М. Морозов, В.Я. Голант, А.А. Елистратова и В.М. Гаевский); то

\footnotetext{
23 Там же. С. 181.

24 Там же. С. 183.
} 
или иное уильямсовское произведение рассматривалось исключительно сквозь призму «идейных задач» и политической направленности. Как правило, критические суждения о его пьесах сводились к череде оскорбительных комментариев и доказательству заведомой ущербности идеологически чуждого автора. Драматурга, уже завоевавшего широкую известность, чьи пьесы с успехом шли по всему миру (в Италии Лукино Висконти в 1947 г. воплотил на сцене «Стеклянный зверинец», а в 1949-м — «Трамвай “Желание”», и в том же году эту пьесу поставил в Англии Лоуренс Оливье, а в Швеции - Ингмар Бергман), в СССР шельмовали, не стесняясь в выражениях. В таком вот искаженном, отвращающем читателей образе Уильямс оставался в СССР до конца 1950-х гг.

По-иному стало рассматриваться творчество Уильямса в эпоху оттепели: идеологизированная, клишированная критика, определяющая талант писателя только по принципу его принадлежности к «своим» и «чужим», если и не потеряла своей актуальности, то смягчилась. Пусть и с неизбежными оговорками и идеологическими инвективами, тон посвященных драматургу публикаций стал заметно меняться. Это очевидно на примере многочисленных критических работ упоминавшегося нами ранее советского литературоведа, автора перевода «Стеклянного зверинца» Г.П. Злобина. В череде отечественных «уильямсоведческих» публикаций эпохи оттепели особое место занимают работы (критические и переводческие), инициированные и «пробитые» именно этим исследователем. Уже первая его статья об американском драматурге, вышедшая в 1959 г. в журнале «Иностранная литература», была полностью посвящена пьесе «Орфей спускается в ад» и отличалась вдумчивым, подробным и заинтересованным анализом ${ }^{25}$. Г.П. Злобин пытался определить эстетическую систему драматургии заокеанского автора: «Уильямс нередко отдает дань натурализму» ${ }^{26}$, и одновременно критик находит в ней «условно-романтический ключ» 27.

В следующем, 1960-м, году в той же «Иностранной литературе» вместе с первой публикацией на русском языке драматургии Уильямса — пьесой «Орфей спускается в ад» в переводе Ю.А. Осноса — была

\footnotetext{
25 Злобин Г.П. Орфей с Миссисипи // Иностранная литература. 1959. № 5.

26 Там же. С. 259.

27 Там же.
} C. $258-260$. 


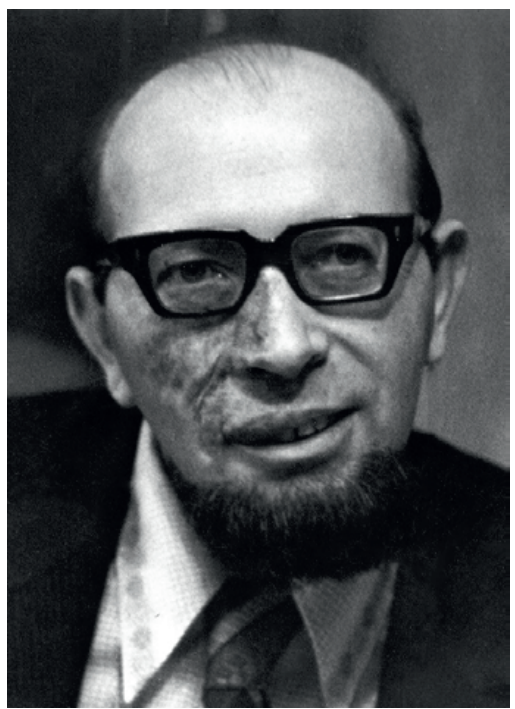

Г.П. Злобин. Середина 1980-х.

напечатана вторая объемная статья Злобина ${ }^{28}$. В ней критик, анализируя уже целый массив пьес драматурга - от «Стеклянного зверинца» до «Пути действительности» (Camino Real, 1953) и «Орфея...», которые он метафорично называет «раздирающим душу криком раненой совести Америки» ${ }^{29}$, — продолжает свою мысль о натуралистическо-романтической основе творчества Т. Уильямса:

Эмпирик по мировоззрению, Уильямс противопоставляет хищному, калечащему личность обществу [...] романтически-отвлеченную веру в то, что «фиалки в горах могут сдвинуть скалы» ${ }^{30}$ (это образ из уильямсовской пьесы «Путь действительности». -

Однако более существенно, что, заявляя об эклектичности художественного стиля драматурга, Г.П. Злобин в этой статье утверждает, что «в лучших пьесах и эпизодах Т. Уильямсу удается все же порваться к реализму» ${ }^{31}$, - а это уже реабилитация американского автора в глазах советского читателя и театрального зрителя, своеобразный «пропуск» для заокеанского драматурга через идеологическую цензуру «холодной войны».

В 1961 г. в истории «советского Уильямса» происходит знаменательное событие - к его драматургии впервые обратился отечественный театр. Пьесу «Орфей спускается в ад» в переводе видного театроведа, критика и переводчика Юрия Александровича Осноса (1911-1978) в качестве бенефиса актрисы В.П. Марецкой воплотил

28 Злобин Г.П. На сцене и за сценой (Пьесы Тенесси Уильямса) // Иностранная литература. 1960. № 7. С. 199-210.

29 Там же. С. 209.

30 Там же. С. 205.

31 Там же. С. 210. 
на сцене Государственный академический театр имени Моссовета (премьера 25 мая 1961 г.) $)^{32}$. Постановщиком выступила И.С. Анисимова-Вульф - кстати, бывшая жена главного режиссера этого театра Ю.А. Завадского. Сейчас трудно предположить, какие аргументы выдвигал тогда театр, оправдывая свой выбор материала для постановки, и выдвигал ли вообще.

Образ Леди в исполнении В. Марецкой «насытился живой плотью». Мужественной, стремящейся к свету, с верой в лучшее будущее, — такой играла Леди В. Марецкая. «Орфея»-Вэла после Г. Некрасова еще долго играли просто как «обаятельного парня с горячим сердцем» [Ходунова 1975: 29].

К сожалению, несмотря на участие ярких актеров (В.П. Марецкая, Р.Я. Плятт и С.Г. Бирман) спектакль не получился и - согласно авторитетному советскому театроведу Б.Н. Любимову - «не удержался ни в репертуаре, ни в памяти...»³. Постановка грешила крайним упрощением философских проблем произведения Уильямса и превратилась в примитивную, вульгарно-социологическую критику «буржуазной» Америки, где главные герои пьесы Вэл и Кэрол выступали мятежниками, бунтующими против политического строя США:

В ней с большой остротой и последовательностью звучит [...] тема беспощадного и страстного обличения современного буржуазного общества, зверски уродующего, калечащего судьбы и души людей, стала главной в этом спектакле ${ }^{34}$.

Но даже такая идеологически выдержанная трактовка не до конца устраивала некоторых советских критиков:

32 Аудиозапись спектакля, сделанная в 1962 г., была издана в формате цифровой аудиокниги. Кроме того, она доступна здесь: Уильямс Теннесси. Орфей спускается в ад // Аудиоспектакли онлайн: коллекция радиоспектаклей и литературных произведений [сайт]. URL: httpsf:/teatr.audio/tennesi-uilyams-orfeyspuskaetsya-v-ad (дата обращения: 11.04.2021).

33 Любимов Б.Н. <Интервью с В.Я. Вульфом>. Театральный мост ... . С. 79.

34 Образцова А.Г. Теннеси Уильямс осуждает (Спектакль Театра имени Моссовета) // Вечерняя Москва. 1961. 11 сентября. № 215 (11500). С. 3. 
Театр должен подойти к пьесе со своим критерием, своей оценкой. В праве режиссера и театра по-своему расставить акценты, в его силах выделить в пьесе то, что в ней заложено подспудно, что выражено автором по тем или иным причинам вполголоса, а то и шепотом. Его обязанность сделать спектакль интересным и нужным советскому зрителю. [...] Театр, в сущности, не разоблачает философии Вэла, рисуя его этаким невольным мучеником. В то же время в спектакле не подчеркнуто и то, чем Вэл привлекателен, - его резкое неприятие окружающей действительности, его своеобразный бунт. Разоблачение нравов современной капиталистической Америки ослабляется утрировкой до неправдоподобия отрицательных персонажей - таких, как шериф Толбот, Джейб, Бьюла и Долли с мужьями. Вот и получилось, что спектакль, который мог стать интересным и нужным, мало что говорит зрителю ${ }^{35}$.

За театр вступилась молодой театровед Инна Натановна Соловьева (р. 1927), в будущем знаток наследия основателей МХАТа:

Может быть, при режиссерской работе над «Орфеем» слишком думали, как оправдать его появление на нашей сцене, - Уильямс разыгран по типу «антиамериканских» спектаклей. Это, конечно, не самый интересный путь. Но у театра имени Моссовета несомненная заслуга: здесь пьесу Уильямса поставили - не только рассуждали, как хорошо было бы ее поставить ${ }^{36}$.

Однако ж грешно укорять театр имени Моссовета, что он упростил философские проблемы пьесы, решая их торопливо и привычно. Ведь нельзя забывать: в театре имени Моссовета Теннесси Уильямса у нас поставили впервые [Соловьева 1966: 153].

Итогом многолетнего исследования Г.П. Злобина творчества американского драматурга стала монографическая глава «Отчаяние и страсти Теннесси Уильямса» [Злобин 1965] в книге 1965 г. «Современная драматургия США», переизданной и дополненной в 1968-м [Злобин 1968: 62-75]. Подчеркнем преемственность традиции отечественного уильямсоведения: в написании второго варианта книги

35 Бахметьева С. Театр - это тоже политика // Молодой коммунист. 1962. № 6. C. 110 ,

36 Соловьева И.Н. «Орфей спускается в ад» // Театр. 1961. № 12. С. 85. 
Г.П. Злобину помогли советы и рекомендации А.А. Елистратовой, о чем он с благодарностью сообщает в предисловии издания (см.: [Злобин 1968: 6]). Другой победой исследователя явилось то, что в 1967 г. он «пробил» статью об Уильямсе в «Театральной энциклопедии», пусть и с необходимой «данью» идеологии в виде оговорок о том, что «пьесы У<ильямса> отмечены натуралистич<еской> зоркостью и социальной слепотой» [Злобин 1967: 327]. Включение американского драматурга в официальную «театральную летопись» СССР позволило в дальнейшем Г.П. Злобину поместить статью об Уильямсе в «Краткую литературную энциклопедию» [Злобин 1972].

Одновременно со Злобиным свой вклад в советское уильямсоведение внес критик и литературовед-американист Морис Осипович Мендельсон (1904-1982). В 1960 г. в газете «Литература и жизнь» он опубликовал статью об американском драматурге под названием «Скованное дарование», в которой остановился на разборе трех пьес «Кошка на раскаленной крыше», «Орфей спускается в ад» и «Внезапно прошлым летом» (Suddenly Last Summer, 1958). Отдавая предпочтение «Орфею», поскольку (как утверждает М.О. Мендельсон) в нем имеется социальный протест и сочувствие к страданиям своих героев, критик заключает статью пессимистическим выводом:

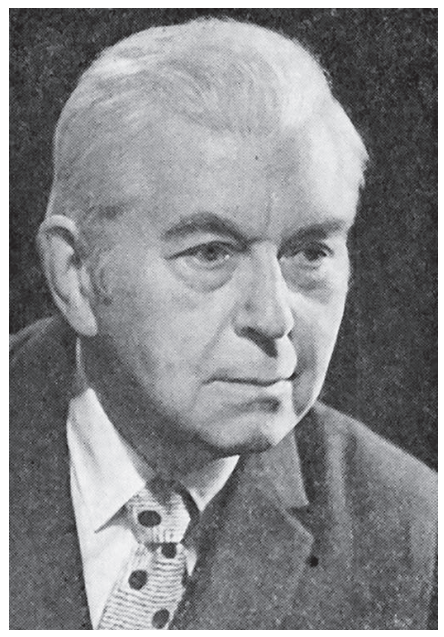

М.О. Мендельсон. 1970-е.

Особенности творчества Теннесси Уильямса показывают, насколько взбаламучен и захламлен бредовыми идеями и декадентскими образами духовный мир писателя. Ложные мысли и безнадежно мрачные видения сковывают и разрушают дарование не лишенного социальной чуткости драматурга ${ }^{37}$.

Сложно переоценить роль в изучении творчества Уильямса, его популяризации в СССР литературоведа-американиста Раисы Давыдовны Орловой (1918-1989), - «одного из первопроходцев на пути к вновь и заново

37 Мендельсон М.О. Скованное дарование // Литература и жизнь. 1960. 2 декабря. № 143 (413). С. 4. 
узнаваемому разностороннему миру, в частности, современной американской литературы» [Гончар 2018: 43]. Ученица А.А. Елистратовой по аспирантуре в ИМЛИ (опять тема преемственности традиций), она пыталась объективно и непредвзято судить об Уильямсе. Когда в середине 1970-х Р.Д. Орлова без ложной скромности писала американскому драматургу, что «делала все возможное, чтобы они (его пьесы. - M. Г.) стали известны у нас» [Орлова 2021: 329], — то в этом она ничуть не погрешила против истины.

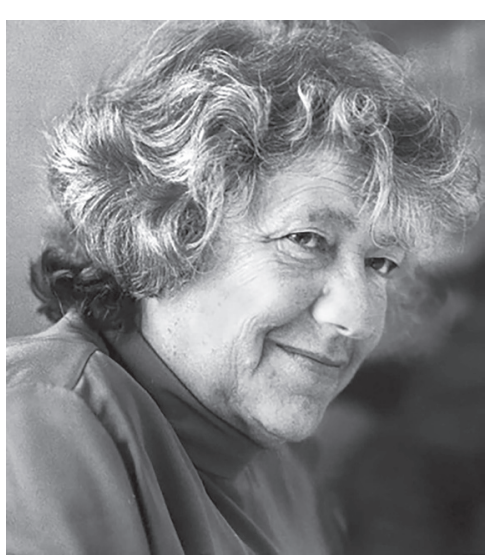

Р.Д. Орлова. 1970-е.

В своей статье 1960 г. «От иллюзий — к правде», написанной совместно со своим мужем и литературоведом Л.З. Копелевым, среди прочих современных американских пьес Р.Д. Орлова останавливается подробно лишь на одной драме Уильямса — «Орфей спускается в ад». Определяя ее стиль, авторы статьи произносят «спасительные слова» о реализме:

От бездушия декадентов драматургию Уильямса отделяют и неподдельное человеколюбие, и упорные искания добрых, нежных, «душевных» героев, и те реалистические средства образотворчества, которые присущи даже его наиболее «трудным», отравленным модернистскими влияниями пьесам. В драме «Орфей спускается в ад» Уильямс, пожалуй, более чем где-либо еще, приблизился к идейно-творческим принципам критического реализма ${ }^{38}$.

Творчество Уильямса, наряду с другими американскими писателями-наследниками «марктвеновских» традиций, рассматривается Р.Д. Орловой также в ее книге «Потомки Гекльберри Финна». Уильямсовской драматургии здесь посвящена отдельная глава, в которой налицо доброжелательный интерес автора к пьесам американского писателя, особенностям его мировосприятия и своеобразию творческого метода. В очередной раз литературовед подчеркивает интерес Уильямса к социальной проблематике:

38 Орлова Р.Д., Копелев Л.3. От иллюзий — к правде // Театр. 1960. № 6. С. 179. 
«Ад» и «Орфей», противопоставленные и связанные, многозначные, символические и реальные, - основные понятия уильямсовского мира (т. е. не только конкретной его пьесы «Орфей спускается в ад». - M. Г.). В этих понятиях есть и элементы социальной критики - ад современной американской жизни, где гибнут в страшных муках любовь, красота, искусство, где гибнут современные Орфеи [Орлова 1964: 259].

В 1967 г. вышел в свет первый в СССР сборник драматургии Уильямса [Уильямс 1967], который сопровождался послесловием литературоведа-американиста и переводчика Владича Алексеевича Неделина (1924-1986), автора перевода «Трамвая “Желание”». Статья изобилует многими оригинальными и аргументированными наблюдениями. Так, ее автор по-своему определяет идею «Трамвая “Желания”»:

Рассматривая «Трамвай» как драму человеческой нетерпимости, мы начинаем понимать то, что казалось столь труднообъяснимым и загадочным многим критикам - почему автор не становится в споре Бланш и Стэнли ни на чью сторону, словно бы признавая: оба правы или неправы поровну — такова жизнь как она есть. Не жизнь - именно нетерпимость как она есть. Схватка без правил. Без удержу, обоюдно бесчестно. [...] Слабейший должен погибнуть, но сильнейший - не выигрывает: в нетерпимости неизбежно деградируют оба. Бланш кончает безумием. Стэнли - оскотиниванием. Их можно жалеть. О них нельзя не грустить, утверждает Уильямс. Об обоих [Неделин 1967: 698].

В.А. Неделин подчеркивает гуманистический пафос и социальную действенность уильямсовской драматургии, окончательно реабилитируя американского автора:

Мы требуем уточнения, мы должны восстановить истину: в пьесах Уильямса человек противостоит (курсив В.А. Неделина. - M. Г.) жестокости, насилию, кошмарам и безумию современной действительности [...], противостоит всему этому, спасая свое достоинство и не покоряясь - даже когда становится жертвой, даже когда безумие этого мира поражает и его самого. В большинстве пьес Уильямса и запечатлены драмы этого противостояния [Неделин 1967: 721]. 
Появление первого сборника драматургии Уильямса на русском языке способствовало тому, что советские люди смогли наконец по-настоящему познакомиться с творчеством американца. Его произведения начали активно ставиться - правда, пока только в провинции. Театры Москвы и Ленинграда не спешили воплощать их на сцене. Лишь один столичный коллектив - Театр имени М.Н. Ермоловой — рискнул это сделать. 7 апреля 1968 г. - спустя шесть лет после «Орфея» Театра имени Моссовета - москвичи увидели «Стеклянный зверинец» (режиссерский дебют молодой эстонской ученицы М.О. Кнебель Каарины Райд).

Работы отечественных исследователей 1960-х гг. (Г.П. Злобина, М.О. Мендельсона, Р.Д. Орловой, В.А. Неделина), ставивших перед собой цель разобраться в своеобразии творческого метода Уильямса, способствовали тому, чтобы его драматургия удостоилась окончательного признания в советской критике. В последующее десятилетие уильямсовское творчество станет объектом научного интереса таких серьезных исследователей, как М.М. Коренева, В.Я. Вульф, К.А. Гладышева, Б.А. Смирнов, а имя американского драматурга прочно войдет в литературную и сценическую жизнь СССР.

Таким образом, за первую четверть века знакомства советских читателей с драматургией Т. Уильямса восприятие, оценки его творчества претерпели существенную эволюцию. Признание таланта заокеанского автора или, наоборот, инвективы в его адрес оказались напрямую связаны с общественно-политической ситуацией в СССР и состоянием советско-американских отношений. Динамика рецепции развивалась от резкого неприятия и отторжения Уильямса как апологета буржуазной, разлагающейся сцены до признания в нем классика американского театра.

Хотя Уильямс никогда и не бывал в нашей стране (в отличие, например, от других заокеанских авторов, писавших для сцены, У. Сарояна, Л. Хеллман, А. Миллера и Э. Олби), однако его пьесы советский театр любил и охотно ставил.

История сохранила интересную беседу драматурга с отечественным поэтом-шестидесятником Е. Евтушенко после офф-бродвейской премьеры его пьесы «Предупреждение малым кораблям» (Small Craft Warnings, 1972):

Он [Евтушенко] рассказал мне, что в России я - миллионер, за счет набежавших там процентов на авторские гонорары за мои пьесы, 
и что мне нужно приехать и пожить там по-королевски. Я ответил: «Будучи тем, чем я являюсь (Уильямс имел в виду свою сексуальную ориентацию. - М. Г.), я лучше буду держаться подальше от России» [Уильямс 2001: 25].

Ждали именитого драматурга в СССР и позже. Так, в конце 1974 г. Р.Д. Орлова в уже цитированном письме к Уильямсу признавалась:

Прошлым летом мы почти были уверены в том, что Вы приедете на фестиваль ${ }^{39}$, но Вас, к сожалению, не было [Орлова 2021: 329].

По указанной ли самим писателем причине, или по какой-то иной (ведь Олби все же бывал у нас), но Уильямс к нам ни разу так и не приехал. Неизвестно, были ли его авторские гонорары в СССР «королевскими», но пьесы его, действительно, с начала 1970-х гг. не сходили со сцены нашей страны. И по сегодняшний день Т. Уильямс является самым популярным американским автором на отечественной сцене.

39 Речь идет о Московском международном кинофестивале, проходившем в июле 1973 г., хотя в его программе и не было ни одной экранизации пьесы Уильямса. 
ПРИЛОЖЕНИЕ

\section{СОВЕТСКАЯ КРИТИКА О Т. УИЛЬЯМСЕ (1947-1969 ГГ.) Библиографический указатель}

\section{7}

Морозов М.М. Во власти доллара // Советское искусство. 1947. 11 октября. № 41 (1077). С. 4.

Морозов М.М. Две культуры // Театр. 1947. № 11. С. 59-64.

\section{8}

Морозов М.М. Культ грубой силы // Советское искусство. 1948. 25 сентября. № 39 (1127). С. 4.

\section{9}

Голант В.Я. Отравители // Звезда. 1949. № 4. С. 132-140. (О Т. Уильямсе - c. 140.)

Театр на службе реакции (Письмо из Нью-Йорка) // Правда. 1949. 6 сентября. № 249 (11356). С. 3.

\section{0}

Лапиикий И. Кризис на Бродвее // Советское искусство. 1950. 14 января. № 3 (1195). С. 4.

\section{1}

Снегов Л. Свидетели банкротства (К итогам кинофестиваля в Венеции) // Советское искусство. 1951. 1 декабря. № 96 (1380). С. 4.

\footnotetext{
1) Приведенный список является попыткой создания полного библиографического указателя советских критических статей о творчестве Т. Уильямса в 1940-1960-е гг. При его составлении были использованы в том числе следующие источники и ресурсы: Либман B.A. Американская литература в русских переводах и критике: библиография (1776-1975). М.: Наука, 1977. 452 с.; Зарубежная драматургия XX века: библиогр. указатель русских переводов и критической литературы на русском языке (1945-1980). М.: Всесоюз. гос. б-ка иностран. лит., 1982. Ч. 2: Норвегия - Югославия. Вспомогательные указатели. 1120 с., а также материалы картотеки «Мировая художественная литература в русских переводах» (или «Картотека А.Д. Умикян») Российской национальной библиотеки (Санкт-Петербург).
} 
Шатова Л. Упадок английского буржуазного театра (По страницам зарубежной печати) // Советское искусство. 1951. 15 августа. № 65 (1349). C. 4.

\section{3}

Белоголовова K. Театральный Бродвей // Театр. 1953. № 8. С. 156-162. (О Т. Уильямсе - с. 158, 160.)

Елистратова А.А. Пропаганда безнадежности (Заметки о современных американских буржуазных пьесах) // Правда. 1953. 24 мая. № 144 (12712). С. 3.

Эйлау Г. Бродвей на Курфюстендамме // Литературная газета. 1953. 17 октября. № 123 (3152). С. 4.

\section{4}

Информация о том, что уже в 1954 г. пьеса «Орфей спускается в ад» была поставлена в Пензенском областном театре драмы им. А.В. Луначарского ${ }^{2)}$ ошибочна, поскольку пьеса была закончена драматургом лишь в 1957 г. Премьера этого спектакля состоялась на десять лет позже - 8 февраля 1964 г. Автор статьи благодарен за эти сведения руководителю литературно-драматургической части Пензенского областного драматического театра им. А.В. Луначарского Виталию Германовичу Соколову (сообщено в письме от 28 апреля 2020 г.).

\section{6}

Изаков Б. В театрах и кино США // Советская культура. 1956. 10 марта. № 30 (422). С. 4.

\section{7}

Павлов М. Гости с Бродвея в Париже // Литературная газета. 1957. 5 февраля. № 16. С. 4.

\section{8}

Гаевский В.M. Теннесси Вильямс - драматург «без предрассудков» // Театр. 1958. № 4. С. 181-183.

Гозенпуд А. О неверии в человека, о нигилизме и «философии» отчаяния // Звезда. 1958. № 7. С. 195-214. (О Т. Уильямсе - с. 212.)

2) См.: Зарубежная драматургия XX века: библиогр. указатель ... . С. 684. 


\section{9}

Злобин Г.П. Орфей с Миссисипи // Иностранная литература. 1959. № 5. C. $258-260$.

\section{0}

Злобин Г.П. В поисках человечности: заметки о новых пьесах американских драматургов // Литературная газета. 1960. 17 марта. № 33 (4158). С. 4.

Злобин Г.П. На сцене и за сценой (Пьесы Тенесси Уильямса) // Иностранная литература. 1960. № 7. С. 199-210.

Марков П.А. Первые впечатления // Театр. 1960. № 6. С. 161-168. (О Т. Уильямсе — с. 167-168.)

Мендельсон М.О. Скованное дарование // Литература и жизнь. 1960. 2 декабря. № 143 (413). С. 4.

Орлова Р.Д., Копелев Л.З. От иллюзий - к правде // Театр. 1960. № 6. C. 169-181.

Сибиряков Н. Говорить должны музы // Театральная жизнь. 1960. № 1. С. 26-29. (О Т. Уильямсе - с. 29.)

\section{1}

Бачелис Т.И. Театр за рубежом. М.: Знание, 1961. 40 с. (Серия «Народный университет культуры») (О Т. Уильямсе - с. 10-11, 14.)

Березницкий Я.А. Два пути? // Театр. 1961. № 2. С. 183-186. (О Т. Уильямсе — с. 183-185.)

Булычевская В. Орфей в неоновом аду // Волга (Астрахань). 1961. 12 октября. № 242 (12620). С. 2. (Рецензия на спектакль «Орфей спускается в ад» Саратовского драм. театра им. К. Маркса.)

Колесова И. Спектакль, зовущий к борьбе // Комсомолец Каспия (Астрахань). 1961. 6 октября. № 120 (721). С. 3. (Рецензия на спектакль «Орфей спускается в ад» Саратовского драм. театра им. К. Маркса.)

Корнилов Е. Правда об американском «рае»// Молот (Ростов-на-Дону). 1961. 8 октября. № 238 (11854). С. 4. (Рецензия на спектакль «Орфей спускается в ад» Ростовского драм. театра им. М. Горького.)

Макарова О. Порабощенные (Гастроли Театра им. Моссовета в Риге) // Ригас Балсс (Голос Риги). 1961. 27 июля. № 176 (1176). С. 6. (Рецензия на спектакль «Орфей спускается в ад» Театра им. Моссовета.) 
Ненахов И. Три часа в аду (Премьера Театра им. М. Горького) // Вечерний Ростов (Ростов-на-Дону). 1961. 22 сентября. № 225 (986). С. 3. (Рецензия на спектакль «Орфей спускается в ад» Ростовского драм. театра им. М. Горького.)

Образиова А.Г. Теннеси Уильямс осуждает (Спектакль Театра им. Моссовета) // Вечерняя Москва. 1961. 11 сентября. № 215 (11500). C. 3 .

Петрейков Л. Свет и тьма // Московская правда. 1961. 30 сентября. № 234 (12674). С. 4. (Рецензия на спектакль «Орфей спускается в ад» Театра им. Моссовета.)

Соловьева И.Н. «Орфей спускается в ад» // Театр. 1961. № 12. С. 83-85. (Рецензия на спектакль «Орфей спускается в ад» Театра им. Моссовета.)

Явчуновский Я. Раненая совесть Америки // Коммунист (Саратов). 1961.3 июня. № 130 (12559). С. 4. (Рецензия на спектакль «Орфей спускается в ад» Саратовского драм. театра им. К. Маркса.)

\section{2}

Алексайте И. Языком театральной правды // Советская Литва (Вильнюс). 1962. 23 июня. № 146 (5787). С. 2-3. (Рецензия на спектакль «Орфей спускается в ад» Гос. акад. театра драмы Литовской ССР, Вильнюс.)

Барсуков Н., Зарубин А. Трагедия Америки // Горьковская правда. 1962. 4 февраля. № 30 (13315). С. 3. (Рецензия на спектакль «Орфей спускается в ад» Горьковского театра драмы им. М. Горького.)

Бахметьева C. Театр - это тоже политика // Молодой коммунист. 1962. № 6. С. 108-112. (О Т. Уильямсе — с. 110.)

Волчек Ю. «Орфей спускается в ад» // Театр. 1962. № 6. С. 96-98. (Рецензия на спектакль «Орфей спускается в ад» Горьковского театра драмы им. М. Горького.)

Евсевьев В. «Орфей спускается в ад»// Таганрогская правда. 1962. 2 сентября. № 176 (10862). С. 4. (Рецензия на спектакль «Орфей спускается в ад» Ростовского драм. театра им. М. Горького.)

Злобин Г.П. Быть или не быть реализму на театре? // Вопросы литературы. 1962. № 3. С. 127-130. (О Т. Уильямсе - с. 129-130.)

Ломоносов А. «Орфей спускается в ад» (Пьеса Т. Уильямса в постановке Горьковского театра драмы) // Советская Кубань (Краснодар). 1962. 11 августа. № 188 (12413). С. 4. (Рецензия на спектакль «Орфей спускается в ад» Горьковского театра драмы им. М. Горького.) 
Лоусон Дж.Г. Современная драматургия США // Иностранная литература. 1962. № 8. С. 186-196. (О Т. Уильямсе — с. 192-194, 196.)

Маликов E. «Страна эта больна...» // Забайкальский рабочий (Чита). 1962. 3 ноября. № 261 (12277). С. 4. (Рецензия на спектакль «Орфей спускается в ад» Читинского драм. театра.)

На селе и в городе // Театральный Ленинград. 1962. № 27. С. 10. (О спектакле «Орфей спускается в ад» Ленинградского обл. театра драмы и комедии.)

Образиова А.Г. Пьесы и спектакли // Современная зарубежная драма. М.: Изд-во Акад. наук СССР, 1962. С. 314-382. (О Т. Уильямсе - с. 355-356, 370, 375-376.)

«Орфей спускается в ад» // Комсомолец Забайкалья (Чита). 1962. 14 ноября. № 135 (1661). С. 4. (Рецензия на спектакль «Орфей спускается в ад» Читинского драм. театра.)

«Орфей спускается в ад» // Театральный Ленинград. 1962. № 9. С. 6. (О спектакле «Орфей спускается в ад» Ленинградского обл. театра драмы и комедии.)

«Орфей спускается в ад» (О предстоящей премьере) // Театральный Ленинград. 1962. № 23. С. 8. (О спектакле «Орфей спускается в ад» Ленинградского обл. театра драмы и комедии.)

Полюхов Н. «Орфей спускается в ад» (Гастроли Гос. русского драмтеатра Эстонской ССР) // Советская Молдавия. 1962. 25 августа. № 200 (5381). С. 4. (Рецензия на спектакль «Орфей спускается в ад» Таллинского русского драм. театра.)

Сидорова И. Которые не продаются... (Спектакль «Орфей спускается в ад» в театре драмы) // Горьковский рабочий. 1962. 3 февраля. № 29 (3350). С. 3. (Рецензия на спектакль «Орфей спускается в ад» Горьковского театра драмы им. М. Горького.)

Снесаревский П., Берештейн П. Орфей побеждает ад // Калининградская правда. 1962. 25 февраля. № 48 (3925). С. 4. (Рецензия на спектакль «Орфей спускается в ад» Калининградского областного драм. театра.)

Сокол Э. Америка глазами американца // Советская Эстония (Таллин). 1962. 11 января. № 9 (5629). С. 3. (Рецензия на спектакль «Орфей спускается в ад» Таллинского русского драм. театра.)

Шалуташвили Н. Мир обреченных («Орфей спускается в ад» на сцене театра им. А.С. Грибоедова) // Заря Востока (Тбилиси). 1962. 7 июня. № 131 (11451). С. 3. (Рецензия на спектакль «Орфей спускается в ад» Тбилисского драм. театра им. А.С. Грибоедова.) 
Шпаковский И. [Луганск] (Информация) // Театр. 1962. № 10. С. 142. (О спектакле «Орфей спускается в ад» Областного русского драм. театра, Луганск.)

Щербина Г. Сегодня у саратовцев (О спектаклях Саратовского драматического театра им. К. Маркса) // Театр. 1962. № 1. С. 158, 160-162. (О спектакле «Орфей спускается в ад» Саратовского драм. театра им. К. Маркса.)

Якубовский А. Зарубежный мир глазами театров // Советская культура. 1962. 17 февраля. № 21 (1357). С. 3. (Рецензия на спектакль «Орфей спускается в ад» Театра им. Моссовета.)

\section{3}

Березницкий Я.А. Статистика, мечты и реальность // Театр. 1963. № 1. С. 117-119. (О Т. Уильямсе — с. 118-119.)

Брусиловская Э. «Орфей спускается в ад» // Тюменская правда. 1963. 20 января. № 17 (5042). С. 3. (Рецензия на спектакль «Орфей спускается в ад» Тюменского обл. драм. театра.)

Гайдабура В. [Запорожье] (Информация) // Театр. 1963. № 3. C. 106. (О спектакле «Орфей спускается в ад» Областного украинского драм. театра им. Н. Щорса, Запорожье.)

Лури С. Грязь на подмостках // Известия. 1963. 30 мая. № 128 (14291). C. 2.

Неделин Н.А. В сумерках психоанализа // Иностранная литератуpa. 1963. № 10. С. 196-216. (О Т. Уильямсе - с. 206.)

Новая постановка Театра драмы и комедии (К предстоящей премьере) // Театральный Ленинград. 1963. № 7. С. 10. (О спектакле «Орфей спускается в ад» Ленинградского обл. театра драмы и комедии.)

Петровский Ю. Не оглядывайся, Орфей! // Новгородская правда. 1963. 3 марта. № 53 (4848). С. 4. (Рецензия на спектакль «Орфей спускается в ад» Ленинградского обл. театра драмы и комедии.)

Сидоров E. «Орфей спускается в ад» // Московский комсомолец. 1963. 15 августа. № 161 (7676). С. 3. (Рецензия на спектакль «Орфей спускается в ад» Ростовского драм. театра им. М. Горького.)

\section{4}

Головня Л. На языке Шекспира // Театр. 1964. № 2. С. 115. (Рецензия на спектакль «Орфей спускается в ад» на англ. языке самодеятельного театра Дома ученых, Москва.) 
Кан И. Трагическая Америка (Гастроли Рыбинского драм. театра) // Ленинская правда (Петрозаводск). 1964. 25 июля. № 173 (13226). С. 2. (Рецензия на спектакль «Орфей спускается в ад» Рыбинского драм. театра.)

Клейнерман Я. «Орфей спускается в ад» // Пензенская правда. 1964. 19 февраля. № 42 (13449). С. 4. (Рецензия на спектакль «Орфей спускается в ад» Пензенского обл. драм. театра им. А.В. Луначарского.)

Ларин Е. Ищем, думаем, творим... // Пензенская правда. 1964. 1 марта. № 52 (13459). С. 4. (Рецензия на спектакль «Орфей спускается в ад» Пензенского обл. драм. театра им. А.В. Луначарского).

Миносян С. «Орфей спускается в ад»// Баку. 1964. 16 июля. № 167 (347). С. 4. (Рецензия на спектакль «Орфей спускается в ад» Ростовского драм. театра им. М. Горького.)

Орлова Р.Д. Ад и Орфей // Орлова Р.Д. Потомки Гекльберри Финна (Очерки современной американской литературы). М.: Сов. писатель, 1964. С. 258-265.

\section{5}

Александров Н. Удача ансамбля («Орфей спускается в ад» в постановке Ногинского драмтеатра) // Коломенская правда. 1965. 15 октября. № 151 (10251). С. 4. (Рецензия на спектакль «Орфей спускается в ад» Ногинского драм. театра.)

Зайцеев Б. Премьера в Ногинском театре // Знамя коммунизма (Ногинск). 1965. 25 апреля. № 51 (11122). С. 4. (Рецензия на спектакль «Орфей спускается в ад» Ногинского драм. театра.)

Злобин Г.П. Отчаяние и страсти Теннесси Уильямса // Злобин Г.П. Современная драматургия США (Критический очерк послевоенного двадцатилетия). М.: Высшая школа, 1965. С. 53-64.

\section{6}

Валин И. Чувство времени (Гастроли Московского обл. драм. театра) // Советская Латвия (Рига). 1966. 27 августа. № 200 (6718). C. 4. (Рецензия на спектакль «Орфей спускается в ад» Московского обл. драм. театра.)

Г. 3. [Злобин Г.П.]. [Рецензия на издание пьесы Т. Уильямса «Молочные реки здесь пересохли» / “The Milk Train Doesn't Stop Here Anymore", NY, 1964] // Современная художественная литература за рубежом (Информ. бюллетень). 1966. № 1. С. 103-106. 
Иванов В. Свет и тени // Ленинская правда (Петрозаводск). 1966. 24 июля. № 170 (13839). С. 3. (Рецензия на спектакль «Орфей спускается в ад» Московского обл. драм. театра.)

Коренева М.M. [Рецензия на книгу: Jackson E.M. "The Broken World of Tennessee Williams", Madison, 1966] // Современная художественная литература за рубежом (Информ. бюллетень). 1966. № 9/10. C. $112-114$.

Лури С. Усеянный трупами Бродвей // Правда. 1966. 4 сентября. № 247 (17564). С. 5.

Неделин Н.А. В сумерках психоанализа // Современная литература за рубежом (Литературно-критические статьи). М.: Советский писатель, 1966. Сб. 2. С. 151-207. (О Т. Уильямсе - с. 159-160, 178-179. Тот же текст, что и в публикации этого автора в 1963 г.).

Соловьева И.Н. Линчевание Орфея // Соловьева И.Н. Спектакль идет сегодня. М.: Искусство, 1966. С. 150-153.

Теплии Е. Мир Теннесси Уильямса // Теплиц Е. Кино и телевидение в США. М.: Искусство, 1966. С. 106-111.

\section{7}

Злобин Г.П. После абсурда (Американская драматургия 60-х годов. Проблемы и стиль) // Иностранная литература. 1967. № 9. С. 206-214. (О Т. Уильямсе — c. 207.)

Злобин Г.П. Уильямс, Теннесси // Театральная энциклопедия: в 5 т. / гл. ред. П.А. Марков. М.: Сов. энциклопедия, 1967. Т. 5. Стб. 326-327.

Колос Г. Диалог через рампу. Минск: Беларусь, 1967. (О спектакле 1962 г. «Орфей спускается в ад» Калининградского обл. драм. театра - с. 211-218.)

Левидова И. [Рецензия на книгу “The Knightly Quest and Other Stories", NY, 1966] // Современная художественная литература за рубежом (Информ. бюллетень). 1967. № 9/10. С. 74-76.

Марков П.А. Первые впечатления. 1959 год // Марков П.А. В театрах разных стран. М.: ВТО, 1967. С. 295-313. (О Т. Уильямсе c. 310-312. Тот же текст, что и в публикации этого автора в 1960 г.).

Неделин B.A. Дорога жизни в драматургии Теннесси Уильямса // Уильямс Т. «Стеклянный зверинец» и еще девять пьес. М.: Искусство, 1967. C. $676-722$. 


\section{8}

Абалкин Н. Надежды и разочарования Уингфилдов // Правда. 1968. 4 июня. № 156 (18203). С. 6.

Андрианов А. В поисках счастья (Премьера телевизионного спектакля) // Волгоградская правда. 1968. 17 мая. № 113 (14960). С. 4. (Рецензия на телевизионный спектакль «Стеклянный зверинец» Волгоградской студии.)

Баух Е. Границы возможностей (К итогам сезона) // Советская культура. 1968. 1 августа. № 90 (3904). С. 3. (Рецензия на спектакль «Трамвай “Желание”» Кишиневского русского драм. театра им. А.П. Чехова.)

Весенние премьеры // Советская культура. 1968. 11 апреля. № 43 (2313). С. 1. (Рецензия на спектакль «Трамвай “Желание”» Кишиневского русского драм. театра им. А.П. Чехова.)

Викторайте E. Человек и одиночество // Комсомольская правда (Вильнюс). 1968. 10 апреля. № 70 (5911). С. 3. (Рецензия на спектакль «Стеклянный зверинец» Вильнюсского русского драм. театра.)

Галустова Э., Картвелишвили В. В долгу перед зрителем (на спектаклях Театра им. А.С. Грибоедова) // Заря Востока (Тбилиси). 1968. 16 июля. № 164 (13311). С. 4. (Рецензия на спектакль «Трамвай “Желание”» Русского драм. театра им. А.С. Грибоедова, Тбилиси.)

Годунавичене Я. В мире иллюзий («Стеклянный зверинец» Т. Уильямса в Вильнюсском русском драм. театре) // Вечерние новости (Вильнюс). 1968. 12 февраля. № 36 (3089). С. 3. (Рецензия на спектакль «Стеклянный зверинец» Вильнюсского русского драм. театра.)

Джаши Л. [Тбилиси] (Хроника) // Театр. 1968. № 9. С. 127. (O спектакле «Трамвай “Желание”» Русского драм. театра им. А.С. Грибоедова, Тбилиси.)

Долматовский Е. Хлеб правды // Известия. 1968. 20 апреля. № 94 (15793). С. 3.

Жуховиикий Л. «Маленький человек» в огромном мире // Советская Литва (Вильнюс). 1968. 8 февраля. № 32 (7501). С. 4. (Рецензия на спектакль «Стеклянный зверинец» Вильнюсского русского драм. театра.)

Злобин Г.П. Отчаяние и страсти Теннесси Уильямса // Злобин Г.П. Современная драматургия США (Критический очерк послевоенного двадцатилетия) / 2-е изд., доп. М.: Высш. школа, 1968. С. 62-75. 
Кирсанов А. «Орфей спускается в ад» // Челябинский рабочий. 1968. 6 ноября. № 262 (14732). С. 4. (Рецензия на спектакль «Орфей спускается в ад» Челябинского театра драмы им. С.М. Цвиллинга.)

Кишинев. Русский драматический театр им. А.П. Чехова (Информация) // Театр. 1968. № 7. С. 122. (О спектакле «Трамвай “Желание”» Кишиневского русского драм. театра им. А.П. Чехова.)

Лалаяни Г. Трагедия Ту Ривера // Коммунист (Ереван). 1968. 11 апреля. № 85 (10311). С. 3. (Рецензия на спектакль «Орфей спускается в ад» Русского драм. театра им. К.С. Станиславского, Ереван.)

Лебедев Г. Путешествие на трамвае «Желание» // Вечерний Кишинев. 1968. 10 июня. № 134 (970). С. 3. (Рецензия на спектакль «Трамвай “Желание”» Кишиневского русского драм. театра им. А.П. Чехова.)

Московские премьеры (Информация) // Театр. 1968. № 4. С. 119. (О спектакле «Стеклянный зверинец» Московского театра им. М.Н. Ермоловой.)

Новиков Н.В. Человек и потребительская идеология (Заметки о пьесах Теннесси Уильямса) // Вопросы философии. 1968. № 4. C. $125-136$.

Образцова А.Г. Жизнь во мгле // Театральная жизнь. 1968. № 18. С. 25-26. (Рецензия на спектакль «Стеклянный зверинец» Московского театра им. М.Н. Ермоловой).

Перов Г. Символы и реальность (О спектакле Республиканского русского театра им. А.П. Чехова «Трамвай “Желание”») // Вечерний Кишинев. 1968. 20 апреля. № 94 (930). С. 3. (Рецензия на спектакль «Трамвай “Желание”» Кишиневского русского драм. театра им. А.П. Чехова.)

Петренко Л. «Стеклянный зверинец» // Омская правда. 1968. 13 октября. № 241 (15114). С. 3. (Рецензия на спектакль «Стеклянный зверинец» Омского драм. театра.)

Петровский И.С. Разговор о театре с позиции режиссера // Вечерний Кишинев. 1968. 10 июня. № 134 (970). С. 3. (Рецензия на спектакль «Трамвай “Желание”» Кишиневского русского драм. театра им. А.П. Чехова.)

Праздников Г. В замкнутом круге // Коммунист (Саратов). 1968. 6 июля. № 156 (14721). С. 3. (Рецензия на спектакль «Стеклянный зверинец» Московского театра им. М.Н. Ермоловой). 
Размахнина В. Поиски и открытия // Красноярский рабочий. 1968. 1 августа. № 178 (14818). С. 3. (Рецензия на спектакль «Стеклянный зверинец» Омского драм. театра.)

«Стеклянный зверинеиз»// Вечерние новости (Вильнюс). 1968. 27 января. № 23 (3076). С. 3. (Рецензия на спектакль «Стеклянный зверинец» Вильнюсского русского драм. театра.)

Стуль M. Изгнанники в родной стране // Комсомолец(Челябинск). 1968. 30 ноября. № 144 (4562). С. 2. (Рецензия на спектакль «Орфей спускается в ад» Челябинского театра драмы им. С.М. Цвиллинга.)

Уэллс Г. Крах психоанализа. От Фрейда к Фромму / пер. с англ. И.Т. Татагощиной, М.Е. Холодовской и М.И. Лисиной. М.: Прогресс, 1968. 288 с. (О Т. Уильямсе — с. 171-174.)

Фомина Н. Каков он, «средний американец»? (О спектакле «Ночь за покером») // Псковская правда. 1968. 1 декабря. № 281 (13215). С. 4. (Рецензия на спектакль «Трамвай “Желание”» Псковского обл. драм. театра им. А.С. Пушкина.)

Чеботаревская T. Варшава, Краков: Двенадцать вечеров // Литературная газета. 1968. 21 августа. № 34 (4164). С. 8.

\section{9}

Божко А. Потери и приобретения // Кузнецкий рабочий (Новокузнецк). 1969. 14 июня. № 118 (10329). С. 3. (Рецензия на спектакль «Стеклянный зверинец» Барнаульского драм. театра.)

Воловик А. Побег из рая // На смену (Свердловск). 1969. 31 мая. № 105 (8584). С. 3. (Рецензия на спектакль «Орфей спускается в ад» Свердловского драм. театра.)

Воловик A. Четыре ступеньки американской трагедии (Гастроли Омского драм. театра) // Вечерний Свердловск. 1969. 10 июля. № 158 (3536). С. 3. (Рецензия на спектакль «Стеклянный зверинец» Омского драм. театра.)

Голер М. «Стеклянный зверинец» // Алтайская правда (Барнаул). 1969. 2 февраля. № 28 (14306). С. 4. (Рецензия на спектакль «Стеклянный зверинец» Барнаульского драм. театра.)

Дрейзлер М. Осторожно: стеклянные фигурки! // Молодежь Молдавии (Кишинев). 1969. 7 января. № 3 (2579). С. 3. (Рецензия на спектакль «Стеклянный зверинец» Кишиневского русского драм. театра им. А.П. Чехова.)

Ковалев И. За одним занавесом - другой // Театр. 1969. № 7. C. $164-165$. 
Коренева М.М. Американская критика о послевоенной драматургии США // Современное литературоведение США. Споры об американской литературе. М.: Наука, 1969. С. 230-273. (О Т. Уильямce - c. 245, 258-266.)

Кутырева А. Общество, несовместимое с гуманизмом // Советская Молдавия (Кишинев). 1969. 10 января. № 8 (10625). С. 4. (Рецензия на спектакль «Стеклянный зверинец» Кишиневского русского драм. театра им. А.П. Чехова.)

Логинова Л. Судьбы без грима // Алтайская правда (Барнаул). 1969. 19 апреля. № 92 (14370). С. 4. (Рецензия на спектакль «Стеклянный зверинец» Барнаульского драм. театра.)

Новая пьеса Т. Уильямса // Литературная газета. 1969. 6 августа. № 32 (4214). С. 13.

Петровский И. Театр и личное мнение критика (По поводу статьи И. Рейдермана «Так просто, что не верится...» в газете «Вечерний Кишинев») // Советская Молдавия (Кишинев). 1969. 30 января. № 27 (1168). С. 4. (О спектакле «Трамвай “Желание”» Кишиневского русского драм. театра им. А.П. Чехова.)

Пульхритудова Е. Ермоловцы // Театр. 1969. № 8. С. 19-20. (О спектакле «Стеклянный зверинец» Московского театра им. М.Н. Ермоловой.)

Рейдерман И. Так просто, что не верится... // Вечерний Кишинев. 1969. 15 января. № 12 (1153). С. 3; 16 января. № 13 (1154). С. 3. (Рецензия на спектакли «Стеклянный зверинец» и «Трамвай “Желание”» Кишиневского русского драм. театра им. А.П. Чехова).

Тайнен К. На сцене и в кино. М.: Прогресс, 1969. 288 с. (О Т. Уильямсе - с. 35, 39-40, 162-164.)

Тубин Я. Орфей в аду // Вечерний Свердловск. 1969. 28 мая. № 121 (3499). С. 3. (Рецензия на спектакль «Орфей спускается в ад» Свердловского драм. театра.)

Хаусманис В. С верой в человека («Трамвай “Желание”» Т. Уильямса в Академическом театре драмы) // Советская Латвия (Рига). 1969. 14 декабря. № 291 (8042). С. 4. (Рецензия на спектакль «Трамвай “Желание”» Рижского театра драмы.)

Черняк Ю. Спускаясь в ад // Уральский рабочий (Свердловск). 1969. 26 октября. № 252 (16436). С. 3. (Рецензия на спектакль «Орфей спускается в ад» Свердловского драм. театра.) 
ЛИТЕРАТУРА

Английские и американские пьесы 1946 - Английские и американские пьесы в одном действии / пер. Льва Шифферса. М.; Л.: Искусство, 1946. 135 с.

Власть и художественная интеллигенция 1999 - Власть и художественная интеллигенция. Документы ЦК РКП(б) - ВКП(б), ВЧК - ОГПУ - НКВД о культурной политике. 1917-1953 гг. М.: Междунар. фонд «Демократия», 1999. 872 c.

Гончар 2018 - Гончар Н.А. К публикации статьи Р.Д. Орловой «Драматургия Сарояна» // Вестник Ереванского университета. Сер.: Русская филология. 2018. № 2. C. 42-51.

Гудков 2021 - Гудков М.М. Первый советский «Трамвай “Желание”» // Современная драматургия. 2021. № 1. С. 237-246.

Гудкова 2009 - Гудкова В.В. «Многих этим воздухом и просквозило...»: антиамериканские мотивы в советской драматургии (1946-1954) // Новое литературное обозрение. 2009. № 1 (95). С. 187-216.

Гудкова 2008 - Гудкова В.В. Рождение советских сюжетов: типология отечественной драмы 1920-х — начала 1930-х годов. М.: Новое литературное обозрение, 2008. 453 с.

Джигарханян, Дубровский 2002 - Джигарханян А.Б., Дубровский В.Я. Я одинокий клоун. М.: АСТ-Пресс Книга, 2002. 331 с.

Жидков 1995 - Жидков В.С. Культурная политика и театр. М.: Изд-во лит. по атом. технике, 1995. 320 с.

Злобин 1965 - Злобин Г.П. Отчаяние и страсти Теннесси Уильямса // Злобин Г.П. Современная драматургия США (Критический очерк послевоенного двадцатилетия). М.: Высш. школа, 1965. С. 53-64.

Злобин 1968 - Злобин Г.П. Современная драматургия США (Критический очерк послевоенного двадцатилетия). Изд. 2-е, доп. М.: Высш. школа, 1968. $148 \mathrm{c}$.

Злобин 1972 - Злобин Г.П. Уильямс, Теннесси // Краткая литературная энциклопедия: в 7 т. / гл. ред. А.А. Сурков. М.: Сов. энцикл., 1972. Т. 7. Стб. 747-748.

Злобин 1967 - Злобин Г.П. Уильямс, Теннесси // Театральная энциклопедия: в 5 т. / гл. ред. П.А. Марков. М.: Сов. энцикл., 1967. Т. 5. Стб. 326-327.

Лапенков 2018 - Лапенков Д.С. Американская драматургия ХХ века: творчество Теннесси Уильямса. Орск: Изд-во Орского гум.-технолог. ин-та, 2018. $223 \mathrm{c}$.

Морозов 1947 - Морозов М.M. Зарубежная пьеса на советской сцене // Советский театр. К тридцатилетию Советского государства. М.: Всерос. театр. о-во, 1947. С. 309-340.

Неделин 1967 - Неделин В.А. Дорога жизни в драматургии Теннесси Уильямса // Уильямс Т. «Стеклянный зверинец» и еще девять пьес. М.: Искусство, 1967. C. $676-722$. 
Орлова 1964 - Орлова Р.Д. Ад и Орфей // Орлова Р.Д. Потомки Гекльберри Финна (Очерки современной американской литературы). М.: Сов. писатель, 1964. C. $258-265$.

Орлова 2021 - Орлова Р. Мосты (русско-американские литературные связи) / вступ. ст., публ. и коммент. В.Н. Абросимовой // Науч.-образоват. центр «Эрудит»: [сетевое издание]. М., 2021. URL: http://erudyt.ru/library/doc/449.html (дата публикации: 27.02.2021).

Симонов 1953 - Симонов К.М. Драматургия, театр и жизнь // Идейность и мастерство: сб. ст. советских писателей о драматургии, 1945-1953. М.: Искусство, 1953. С. 26-33.

Смелянский 1989 - Смелянский А.М. Профессия - артист // Станиславский К.С. Собр. соч.: в 9 т. М.: Искусство, 1989. Т. 2: Работа актера над собой. Ч. 1. С. 5-38.

Соловьева 1998 - Соловьева И.Н. «Зеленая улица» // Московский Художественный театр. Сто лет: в 2 т. М.: Моск. Худож. театр, 1998. Т. 1: Спектакли и сценография. С. 172-174.

Соловьева 1966 - Соловьева И.Н. Спектакль идет сегодня. М.: Искусство, 1966. 184 с.

Сталин и космополитизм 2005 - Сталин и космополитизм: документы Агитпропа ЦК КПСС. 1945-1953 / сост. Д.Г. Наджафов, 3.С. Белоусова. М.: Междунар. фонд «Демократия»; Материк, 2005. 768 с.

Уильямс 2001 - Уильямс T. Мемуары / пер. с англ. А. Чеботаря. М.: Авантитул; Олма-Пресс, 2001. 352 с.

Уильямс 1960 - Уильямс Т. Орфей спускается в ад / пер. Ю.А. Осноса // Иностранная литература. 1960. № 7. С. 54-106.

Уильямс 1961 - Уильямс T. Орфей спускается в ад (Певец и ночь) / пер. Ю.А. Осноса. М.: ВУОАП, 1961. 106 с.

Уильямс 1967 - Уильямс T. «Стеклянный зверинец» и еще девять пьес. М.: Искусство, 1967. 723 с.

Ходунова 1975 - [Ходунова E.M.] Зарубежная драматургия на советской сцене в сезонах 1972-1973 и 1973-1974 гг.: обзорная информация. М.: Гос. б-ка им. В.И. Ленина, 1975. 43 с.

Черкасский 2016 - Черкасский С.Д. Мастерство актера: Станиславский - Болеславский - Страсберг: История. Теория. Практика. СПб.: РГИСИ, 2016. 814 c.

\section{REFERENCES}

Angliiskie i amerikanskie p'esy 1946 - Angliiskie $i$ amerikanskie p'esy $v$ odnom deistvii [English and American Plays in One Act]. Translated by Lev Shiffers. Moscow: Iskusstvo Publ., 1946. (In Russ.) 
Cherkasskii 2016 - Cherkasskii, Sergei D. Masterstvo aktera: Stanislavskii - Boleslavskii - Strasberg: Istoriia. Teoriia. Praktika [Acting Technique: Stanislavsky - Boleslavsky - Strasberg; History, Theory and Practice]. St. Petersburg: RGISI Publ., 2016. (In Russ.)

Dzhigarkhanian, Dubrovskii 2002 — Dzhigarkhanian, Armen B., and Viktor Ia. Dubrovskii. Ia odinokii kloun [I'm a Lonely Clown ]. Moscow: AST-Press Kniga Publ., 2002. (In Russ.)

Gonchar 2018 - Gonchar, Nataliia A. "K publikatsii stat'i R.D. Orlovoi Dramaturgiia Saroiana" ["To the Publication of the Article by R.D. Orlova Saroyan's Dramaturgy"]. Vestnik Erevanskogo universiteta. Seriia: Russkaia filologiia [Bulletin of Yerevan University. Series: Russian Philology], no. 2 (2018): 42-51. (In Russ.)

Gudkov 2021 — Gudkov, Maksim M. "Pervyi sovetskii Tramvai 'Zhelanie"” ["The First Soviet Streetcar Named Desire"]. Sovremennaia dramaturgiia [Modern Drama ], no. 1 (2021): 237-246. (In Russ.)

Gudkov, Freese 2022 - Gudkov, Maksim, and Michael Freese. "The First Major Soviet Streetcar Named Desire.” The Tennessee Williams Annual Review, no. 21 (2022, forthcoming). https://tennesseewilliamsstudies.org/journal/index.php.

Gudkova 2009 — Gudkova, Violetta V. "“Mnogikh etim vozdukhom i proskvozilo...': antiamerikanskie motivy v sovetskoi dramaturgii (1946-1954)" [“"Many People Were Blown Through by This Air...': Anti-American Motives in Soviet Drama (1946-1954)"]. Novoe literaturnoe obozrenie [New Literary Observer] 95, no. 1 (2009): 187-216. (In Russ.)

Gudkova 2008 - Gudkova, Violetta V. Rozhdenie sovetskikh siuzhetov: tipologiia otechestvennoi dramy 1920-kh - nachala 1930-kh godov [The Birth of Soviet Plots: The Typology of Russian Drama of the 1920s - early 1930s]. Moscow: Novoe literaturnoe obozrenie Publ., 2008. (In Russ.)

Khodunova 1975 - [Khodunova, Elena M.] Zarubezhnaia dramaturgiia na sovetskoi stsene $v$ sezonakh 1972-1973 i 1973-1974 gg.: obzornaia informatsiia [Foreign Drama on the Soviet Stage in the Seasons 1972-1973 and 1973-1974: Review]. Moscow: Lenin State Library Publ., 1975. (In Russ.)

Lapenkov 2018 — Lapenkov, Denis S. Amerikanskaia dramaturgiia XX veka: tvorchestvo Tennessi Uil'iamsa [American Drama of the Twentieth Century: The Work of Tennessee Williams]. Orsk: Izdatel'stvo Orskogo gumanitarno-tekhnologicheskogo instituta Publ., 2018. (In Russ.)

Morozov 1947 - Morozov, Mikhail M. “Zarubezhnaia p'esa na sovetskoi stsene" ["Foreign Play on the Soviet Stage"]. In Sovetskii teatr. K tridtsatiletiiu Sovetskogo gosudarstva [Soviet Theater: To the Thirtieth Anniversary of the Soviet State], 309-340. Moscow: Vserossiiskoe teatral'noe obshchestvo Publ., 1947. (In Russ.)

Nedelin 1967 - Nedelin, Vladich A. "Doroga zhizni v dramaturgii Tennesci Uil'iamsa" ["The Road of Life in the Drama of Tennessee Williams"]. In "Stekliannyi zverinets" $i$ eshche deviat' p'es ["The Glass Menagerie" and Nine Other Plays] by Tennessee Uil'iams, 676-722. Moscow: Iskusstvo Publ., 1967. (In Russ.) 
Orlova 2021 - Orlova, Raisa D. "Mosty (russko-amerikanskie literaturnye sviazi)" ["Bridges (Russian-American Literary Connections)"], edited by Valeria N. Abrosimova, published February 27, 2021. Nauchno-obrazovatel'nyi tsentr "Erudit" [Scientific and Educational Center "Erudit”] (website). http://erudyt.ru/library/ doc/449.html. (In Russ.)

Orlova 1964 - Orlova, Raisa D. "Ad i Orfei” ["Hell and Orpheus"]. In Potomki Gekl'berri Finna (Ocherki sovremennoi amerikanskoi literatury) [The Descendants of Huckleberry Finn: Essays on Modern American Literature], 258-265. Moscow: Sovetskii pisatel' Publ., 1964. (In Russ.)

Simonov 1953 - Simonov, Konstantin M. "Dramaturgiia, teatr i zhizn"” ["Drama, Theater, and Life"]. In Ideinost' i masterstvo: sbornik statei sovetskikh pisatelei o dramaturgii, 1945-1953 [Ideality and Skill: Collection of Articles of Soviet Writers on Drama; 1945-1953], 26-33. Moscow: Iskusstvo Publ., 1953. (In Russ.)

Smelianskii 1989 - Smelianskii, Anatolii M. "Professiia — artist" ["Profession is an Actor"]. In Sobranie sochinenii: v 9 t. [Collected Works: in 9 vols.] by Konstantin Stanislavskii, vol. 2, pt. 1, pp. 5-38. Moscow: Iskusstvo Publ., 1989. (In Russ.)

Solov'eva 1966 - Solov'eva, Inna N. Spektakl' idet segodnia [The Play Is on Today]. Moscow: Iskusstvo Publ., 1966. (In Russ.)

Solov'eva 1998 - Solov'eva, Inna N. "Zelenaia ulitsa" ["Green Street"]. In Moskovskii Khudozhestvennyi teatr. Sto let: $v 2$ t. [Moscow Art Theater: One Hundred Years; in 2 vols.], 1:172-174. Moscow: Moskovskii Khudozhestvennyi teatr Publ., 1998. (In Russ.)

Stalin i kosmopolitizm 2005 - Stalin i kosmopolitizm: dokumenty Agitpropa TsK KPSS. 1945-1953 [Stalin and Cosmopolitanism: Documents of Agitprop, CPSU Central Committee; 1945-1953]. Editors Dzhakhangir G. Nadzhafov, Zinaida S. Belousova. Moscow: Mezhdunarodnyi fond "Demokratiia" Publ.; Materik Publ., 2005. (In Russ.)

Vlast' i khudozhestvennaia intelligentsiia 1999 - Vlast' $i$ khudozhestvennaia intelligentsiia. Dokumenty TsK RKP(b) - VKP(b), VChK - OGPU - NKVDo kul'turnoi politike. 1917-1953 gg. [Power and Artistic Intelligentsia: Documents of the Central Committee of the RCP(b) - CPSU(b) - CHEKA - OGPU - NKVD on Cultural Policy; 1917-1953]. Moscow: Mezhdunarodnyi fond "Demokratiia" Publ., 1999. (In Russ.)

Williams 1967 - Williams, Tennessee. The Glass Menagerie. In Six Modern American Plays, 271-340. New York: Modern Library, 1967.

Williams 2001 - Williams, Tennessee. Memuary [Memoirs]. Translated by Aleksandr Chebotar'. Moscow: Avantitul Publ.; Olma-Press Publ., 2001. (In Russ.)

Williams 1960 - Williams, Tennessee. Orfei spuskaetsia $v$ ad [Orpheus Descending]. Translated by Iurii A. Osnos. Inostrannaia literatura [Foreign Literature], no.7 (1960): 54-106. (In Russ.)

Williams 1961 — Williams, Tennessee. Orfei spuskaetsia v ad (Pevets i noch') [Orpheus Descending (The singer and the night)]. Translated by Iurii A. Osnos. Moscow: VUOAP Publ., 1961. (In Russ.) 
Williams 1967 - Williams, Tennessee. "Stekliannyi zverinets" i eshche deviat' p'es ["The Glass Menagerie" and Nine Other Plays]. Moscow: Iskusstvo Publ., 1967. (In Russ.)

Zhidkov 1995 — Zhidkov, Vladimir S. Kul'turnaia politika i teatr [Cultural Policy and Theater]. Moscow: Izdatel'stvo literatury po atomnoi tekhnike Publ., 1995. (In Russ.)

Zlobin 1965 —Zlobin, Georgii P. "Otchaianie i strasti Tennessi Uil'iamsa" ["The Despair and Passion of Tennessee Williams"]. In Sovremennaia dramaturgiia SShA (Kriticheskii ocherk poslevoennogo dvadtsatiletiia) [Modern Drama in the USA (A Critical Essay of the Post-War Twentieth Anniversary)], 53-64. Moscow: Vysshaia shkola Publ., 1965. (In Russ.)

Zlobin 1968 - Zlobin, Georgii P. Sovremennaia dramaturgiia SShA (Kriticheskii ocherk poslevoennogo dvadtsatiletiia) [Modern Drama in the USA (A Critical Essay of the Post-War Twentieth Anniversary)], 2nd ed. Moscow: Vysshaia shkola Publ., 1968. (In Russ.)

Zlobin 1972 — Zlobin, Georgii P. "Uil'iams, Tennessi" ["Williams, Tennessee"]. In Kratkaia literaturnaia entsiklopediia: $v$ t. [Short Literary Encyclopedia: in 7 vols.], vol. 7, cols. 747-748. Moscow: Sovetskaia entsiklopediia Publ., 1972. (In Russ.)

Zlobin 1967 - Zlobin, Georgii P. "Uil'iams, Tennessi” ["Williams, Tennessee"]. In Teatral'naia entsiklopediia: $v 5$ t. [Theater Encyclopedia: in 5 vols.], vol. 5, cols. 326-327. Moscow: Sovetskaia entsiklopediia Publ., 1967. (In Russ.) 